\title{
In-Situ LA-ICP-MS Uraninite U-Pb Dating and Genesis of the Datian Migmatite-Hosted Uranium Deposit, South China
}

\author{
Long Cheng ${ }^{1}$, Chengjiang Zhang ${ }^{1, *}$, Hao Song ${ }^{1,2, *}$ (1) and Qian Cheng ${ }^{3}$ \\ 1 College of Earth Science, Chengdu University of Technology, Chengdu 610059, China; \\ chenglong@stu.cdut.edu.cn \\ 2 Key Laboratory of Nuclear Techniques in Geosciences of Sichuan Province, \\ Chengdu University of Technology, Chengdu 610059, China \\ 3 College of Civil Engineering, Sichuan University of Science and Engineering, Zigong 643000, China; \\ chengqian614@163.com \\ * Correspondence: zcj@cdut.edu.cn (C.Z.); songhao2014@cdut.edu.cn (H.S.)
}

Citation: Cheng, L.; Zhang, C.; Song, H.; Cheng, Q. In-Situ LA-ICP-MS Uraninite U-Pb Dating and Genesis of the Datian MigmatiteHosted Uranium Deposit, South China. Minerals 2021, 11, 1098. https://doi.org/10.3390/ $\min 11101098$

Academic Editor: Jaromír Leichmann

Received: 21 August 2021

Accepted: 29 September 2021

Published: 6 October 2021

Publisher's Note: MDPI stays neutral with regard to jurisdictional claims in published maps and institutional affiliations.

Copyright: (C) 2021 by the authors Licensee MDPI, Basel, Switzerland. This article is an open access article distributed under the terms and conditions of the Creative Commons Attribution (CC BY) license (https:/ / creativecommons.org/licenses/by/ $4.0 /)$.

\begin{abstract}
The Datian uranium deposit is a migmatite-hosted, high temperature, hydrothermal deposit in the Kangdian region. Detailed information on the chemical composition and formation age of the uraninite remains lacking, which impedes our understanding of uraninite genesis. Two phases of uraninite have been identified according to their relationships with other minerals and their field relationships. The phase 1 (Ur1) uraninite is characterized by local development of microfractures and pores in the crystal of uraninite, a scattered distribution, and irregular crystal shapes, and it is associated with ilmenite, biotite, and rare earth element (REE) minerals (monazite and xenotime). The phase 2 uraninite (Ur2) has anhedral crystal shapes with well-developed microfractures and pores and is associated with pyrite, albite, pyrrhotite, molybdenite, zircon, and chlorite. X-ray element mapping revealed that the distributions of $\mathrm{U}, \mathrm{Th}$, and $\mathrm{Pb}$ in the $\mathrm{Ur} 1$ uraninite are homogeneous, whereas those in the Ur2 uraninite are heterogeneous. The results of the electron microprobe analysis (EMPA) show that the $\mathrm{UO}_{2}$ and $\mathrm{PbO}$ contents of the Ur1 and Ur2 uraninite do not vary significantly. The high $\mathrm{ThO}_{2}$ contents of the Ur1 (1.08-1.68 wt \%) and Ur2 uraninite (3.41-4.83 wt \%) indicate that they formed at different temperatures. The laser ablation inductively coupled plasma mass spectrometry (LA-ICP-MS) analysis results show that the $\sum$ REE of the Ur1 uraninite (3747.5-7032.3 ppm) is lower than that of the Ur2 uraninite (8369.2-11,484.3 ppm), and the REE patterns of the Ur1 and Ur2 uraninite are sickle-shaped with large negative Eu anomalies. The LA-ICP-MS U-Pb dating results revealed that the ages of the Ur1 $(841.4 \pm 4.0 \mathrm{Ma})$ and Ur2 (834.5 $\pm 4.1 \mathrm{Ma}-837.2 \pm 4.5 \mathrm{Ma})$ uraninite are in consistent with that of the migmatite. Thus, the Datian uranium deposit underwent at least two hydrothermal events, and the uraninite was formed due to the migmatization.
\end{abstract}

Keywords: migmatite hosted Datian uranium deposit; Kangdian region; uraninite; LA-ICP-MS $\mathrm{U}-\mathrm{Pb}$ geochronology

\section{Introduction}

Granular uraninite occurs in magmatic-type uranium deposits, Na-metasomatic type uranium deposits, unconformity-related uranium deposits, and granite-type uranium deposits, but the crystal grains are small [1-4]. Although basin-related uranium deposits are the main source of uranium ore around the world [5], some of the uranium deposits that have close spatial relationships with migmatites are also important sources of uranium ore. Some of the uranium deposits in the Central Ukrainian Uranium Province are hosted in migmatite or the rock surrounding the deposit is migmatite. The average grade of these uranium deposits is 0.06 to $0.21 \mathrm{wt} \%$, and the total resources exceed 300,000 $\mathrm{t} \mathrm{U}$ [6]. Some uranium mineralization is also found in the migmatites in the Lufilian belt in Zambia [7-10]. The ore minerals of these uranium deposits and occurrences are mainly composed of uraninite and brannerite $[6,8,9,11]$. In recent years, several migmatite hosted uranium deposits 
(or occurrences) have been found in the Kangdian region [12]. Uraninite occurs in leucosomes or melanosomes of migmatite, and the grain size can be up to $1 \mathrm{~cm}[12,13]$. Extensive geological and geochemical studies of these deposits have been conducted [13-18]. However, the ages of the uraninite are poorly restricted. Previous studies have reported four main generations of uranium mineralization at $\sim 950,850-821,776-740$, and $\sim 240 \mathrm{Ma}$ in the Kangdian region [13]. These mineralization ages have not been substantiated by direct dating of the uraninite in the deposits. In addition, these studies relied on bulk analysis, which cannot distinguish between the different generations of fine-grained uraninite and the micron-scale alteration zones.

The Datian uranium deposit, which is hosted in migmatite, was the first uranium deposit explored in the Kangdian region. In recent years, many studies have been conducted on the Datian uranium deposit, such as studies of the geochemical characteristics of the host rocks [12,14], the formation ages of the migmatite and granitic dikes [17,19-22], and electron microprobe analysis (EMPA) of the composition and U-Th-Pb chemical ages of the uraninite [23]. Although a great deal of research has been conducted, several issues remain to be explored. First, the origin of the uraninite is still controversial. Other scholars have concluded that the uraninite was formed during the migmatization, which provided the ore-forming fluid and materials $[14,19]$. However, some scholars believe that the uraninite was formed by the intrusive magmatic (granitic) veins, which provided the ore-forming fluid and extracted the uranium from the migmatite after the formation of the migmatite $[18,20-22]$. Second, only one generation of uranium mineralization was identified via EMPA U-Th-Pb chemical dating, but hydrothermal uranium deposits are usually characterized by multi-stage mineralization. In addition, several factors may have influenced the reliability of the EMPA chemical dating. These include significant common $\mathrm{Pb}$ and the degree of uraninite weathering, which were not considered when calculating the age. The age of the uraninite was only confirmed via EMPA chemical dating, and direct dating of the uraninite is lacking. Thus, the goals of this study are (i) to confirm the composition and $\mathrm{U}-\mathrm{Pb}$ isotope compositions of the uraninite and on the basis of this and the petrological features, to divide the metallogenic generations and compare the compositions of the different generations of uraninite via laser ablation inductively coupled plasma mass spectrometry (LA-ICP-MS) microanalysis; and (ii) to investigate the genesis of the uraninite on the basis of its composition.

\section{Geological Background}

The Kangdian region is located in the southwestern margin of the Yangtze Block in South China (Figure 1). The Yangtze Block is characterized by Archean and Paleoproterozoic crystalline basement and widely distributed Neoproterozoic igneous and sedimentary rocks overlain by Paleozoic and Lower Mesozoic stratum [24]. The basement stratum is composed of argillaceous to arenaceous sedimentary rocks, which have been metamorphosed into rocks of the greenschist to granulite facies [25]. Paleoproterozoic to Neoproterozoic metamorphic complex, low-grade metamorphic sedimentary rocks, and clastic rocks are mainly exposed in the Kangdian region in the western margin of the Yangtze Block [26]. These complexes have a banded distribution, are about $700 \mathrm{~km}$ long from north to south, and are locally intruded by Neoproterozoic granite. Traditionally, they have been considered to be the crystalline basement of the Yangtze Block and are usually referred to as the gray gneisses $[27,28]$. These complexes are called the Kangding complex (or Kangding group) in Sichuan Province. The lithology of the Kangding complex is mainly granitic gneiss, which is locally associated with amphibolite and granulite. Migmatite, argillaceous gneiss, mica schist, marble, and quartzite occur locally in the Kangding complex [29]. In the Neoproterozoic, a collision orogeny occurred in the Kangdian region in South China, which resulted in local migmatization of the Kangding complex [14,26]. In the Neopaleozoic, a large number of basic magmatic rocks intruded in Kangdian region, the most famous of which is the Emeishan basalt [30]. 


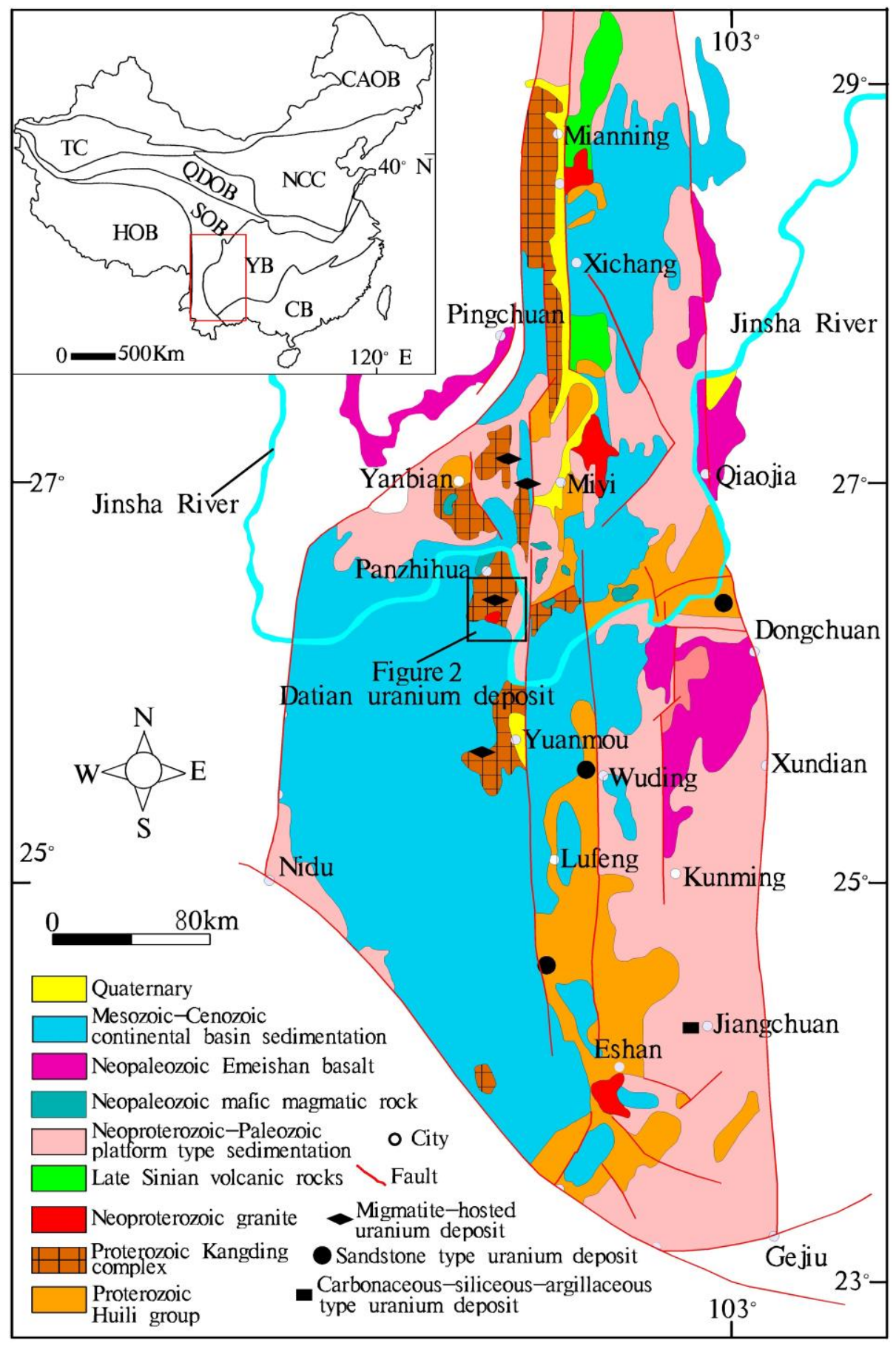

Figure 1. Simplified geologic map of the Kangdian region in the southwestern margin of the Yangtze Block showing the distribution of the Kangding complex (modified from Zhang et al. [12]). CAOB = central Asian orogenic belt, $\mathrm{HOB}=$ Himalayan orogenic belt, $\mathrm{TC}=$ Tarim Craton, $\mathrm{QDOB}=$ Qinling-Dabie orogenic belt, $\mathrm{YB}=$ Yangtze Block, NCC = North China Craton, $\mathrm{CB}=$ Cathaysian Block, $\mathrm{SOB}=$ Sanjing orogenic belt.

Datian uranium deposit is located in Panzhihua City. The Datian uranium deposit is hosted in the Kangding complex in the Kangdian region. The Kangding complex is divided into the lower Zanli Formation and the upper Lengzhuguan Formation in the Datian area (Figure 2). The Lengzhuguan Formation consists of granulite, gneiss, schist, and phyllite. The Zanli Formation is composed of migmatized amphibolite, brecciated migmatite, and hornblende plagiogneiss, with local amphibolite veins. The Datian uranium deposit is hosted in the lower Zanli Formation, which can be divided into three lithologic members. 
(i) The lithology of the third member of the Zanli Formation consists of migmatized plagioclase amphibolite and plagioclase amphibolite gneiss, and their protolith is mafic magmatic rocks [18]. (ii) The second member of the Zanli Formation is composed of biotite quartz schist, graphite-bearing biotite plagioclase gneiss, and biotite plagioclase migmatite, and their protolith is sedimentary rocks [18]. (iii) The first member of the Zanli Formation consists of augen gneiss and augen migmatite, and their protolith is felsic magmatic rocks [18]. The uranium mineralization mainly occurs in the second member, in which graphite mineralization also occurs. Magmatic rocks are widely present in the Datian area (Datian quartz diorite and Heime granite; Figure 2). The Datian quartz diorite formed at 748-770 Ma [19], and the Heime granite formed at 745-783 Ma [14]. The granite and diabase veins formed at 765-778 Ma and 770-780 Ma, respectively [21].

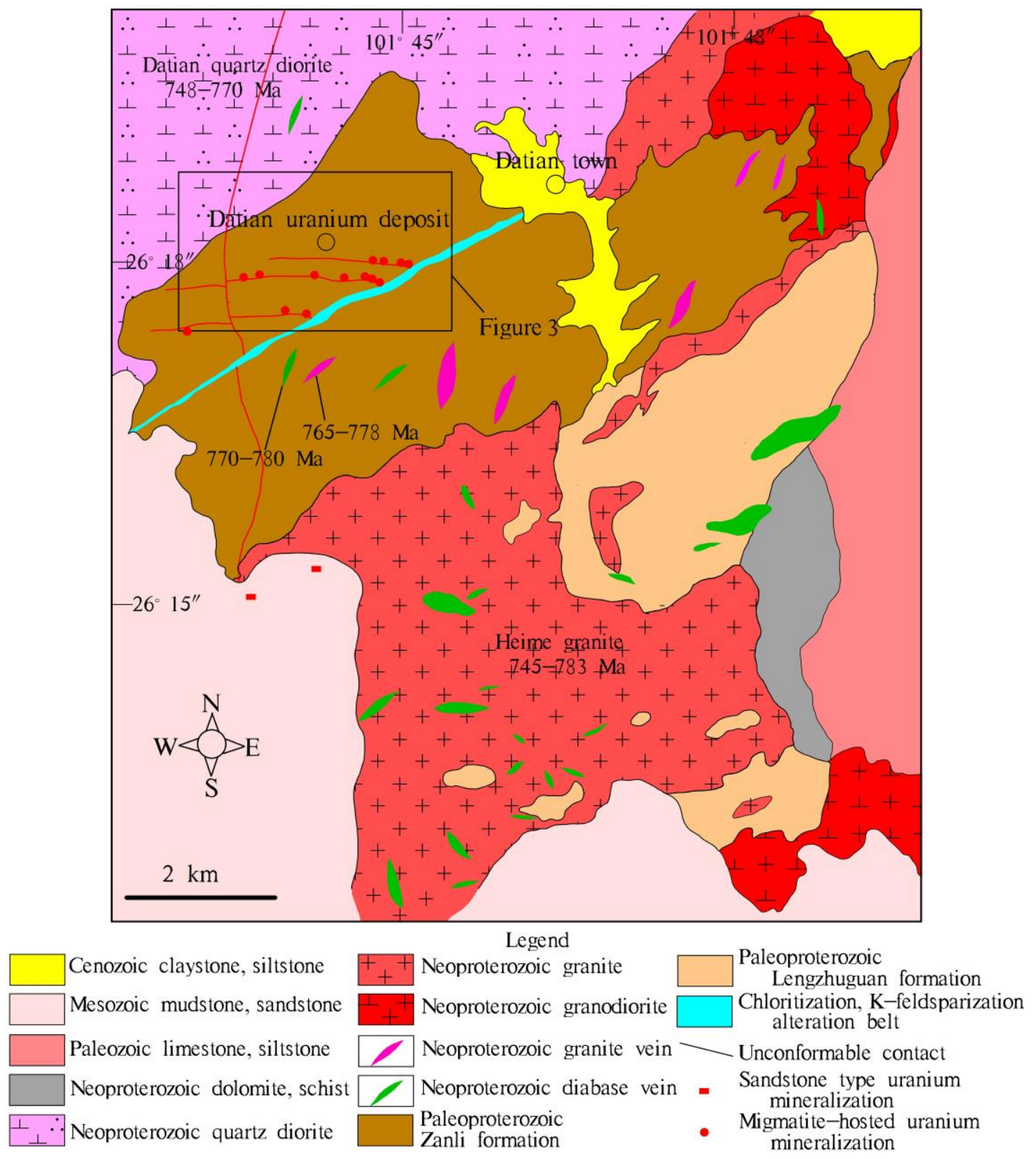

Figure 2. Schematic geologic map of the Datian area. The age of the Datian quartz diorite, Heime granite, granite vein, and diabase veins are from the literature $[14,19,21]$.

The Datian uranium deposit occurs in the migmatite of the Zanli Formation (Figure 3), and the ore body is strictly controlled by brittle-ductile faults. There are four faults (F1, F2, 
F3, and F4) in the Datian uranium deposit. Albitization, zoisitization, and chloritization occurred in faults F1, F2, and F4, while K-feldsparization and chloritization occurred in fault F3. There are three main mineralization zones (I, II, and III) in the Datian uranium deposit, which are located in the F1, F2, and F4 fault respectively. Seventeen deep orebodies have been identified in uranium ore belt I, two orebodies in uranium ore belt II, and four in uranium ore belt III. These deep orebodies are lenticular and vein-like. These deep orebodies are 200-500 $\mathrm{m}$ in length and 50-150 $\mathrm{m}$ in width (trend ENE and dip 55 67 ESE). The thickness of the orebodies is $0.73-1.14 \mathrm{~m}$, and the grade is $0.12-0.6 \mathrm{wt} \% \mathrm{U}$. Uraninite, coffinite, pyrrhotite, molybdenite, and pyrite are the main ore minerals, and chalcopyrite, monazite, xenotime, and ilmenite are minor phases. The gangue minerals include plagioclase, graphite, albite, amphibole, quartz, biotite, chlorite, and a small amount of sphene, and apatite.

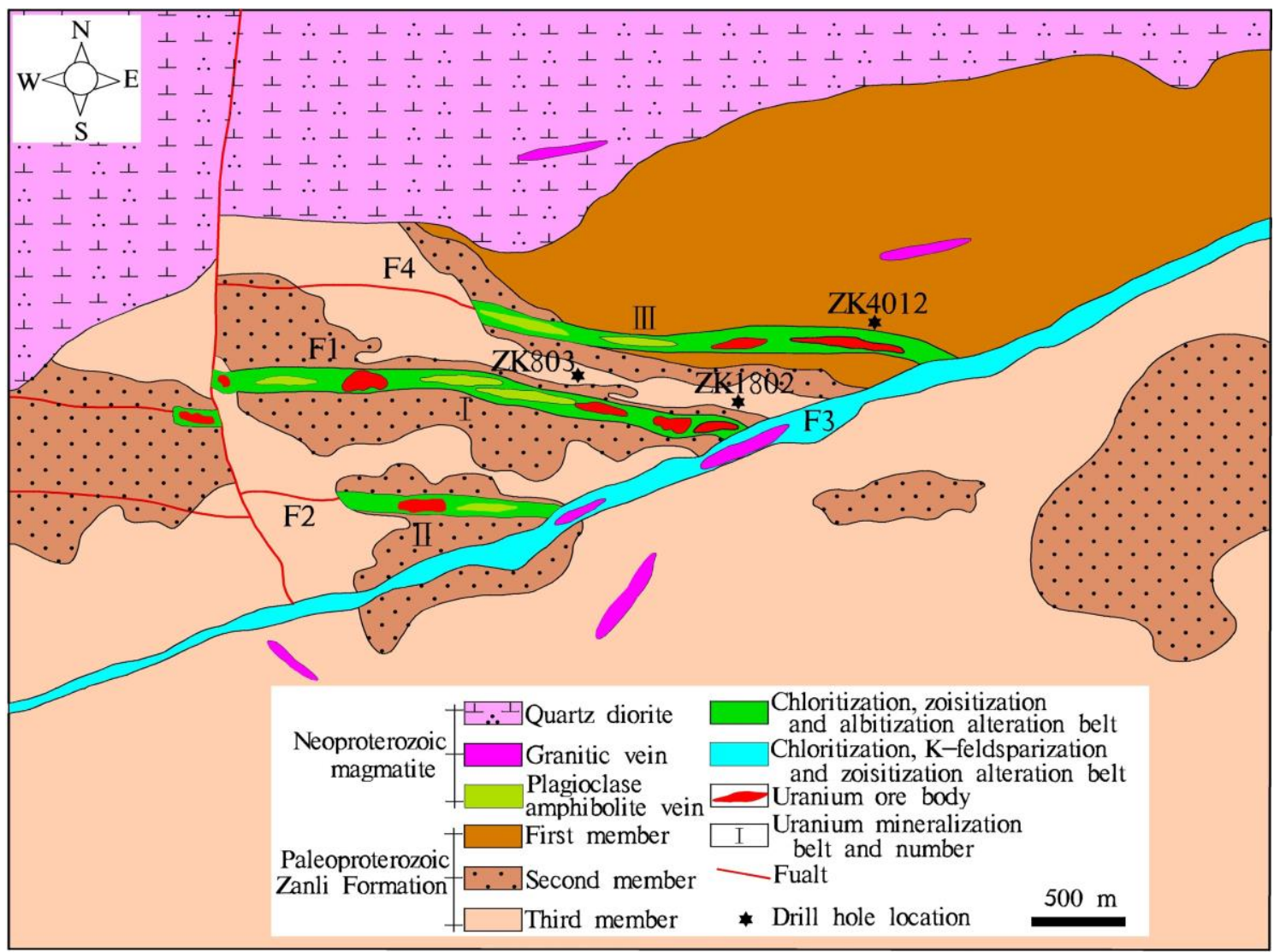

Figure 3. Schematic geologic map of the Datian uranium deposit (modified from Sun et al. [18]).

\section{Analytical Methods}

Three uraninite samples from the Datian uranium deposit were collected and analyzed (Figure $4 \mathrm{a}, \mathrm{b}, \mathrm{e}$ and Figure $5 \mathrm{a}, \mathrm{d}, \mathrm{g}$ ). All of the samples are fresh and were collected from drill holes in the Datian uranium deposit. A mineralogical study was conducted by use of a polarizing microscope (Nikon, LV50NPOL) at the Chengdu University of Technology, Chengdu, China. The targets for the EMPA analysis were selected on the basis of the mineralogical study and backscattered electron (BSE) images of the uraninite.

\subsection{Electron Microprobe Analysis (EMPA)}

The EMPA analysis was conducted at the Beijing Research Institute of Uranium Geology, Beijing, China. The backscattered electron (BSE) images and composition analysis of the uraninite were conducted by use of a JEOL- 8100 instrument with a four-wavelength dispersion spectrometer and an Oxford Inca energy dispersion spectrometer. The EMPA 
beam diameter was modulated between $1 \mu \mathrm{m}$ and $10 \mu \mathrm{m}$ according to the size of the uraninite. The accelerating voltage and beam current were $20 \mathrm{ke} \mathrm{V}$ and $20 \mathrm{nA}$, respectively.
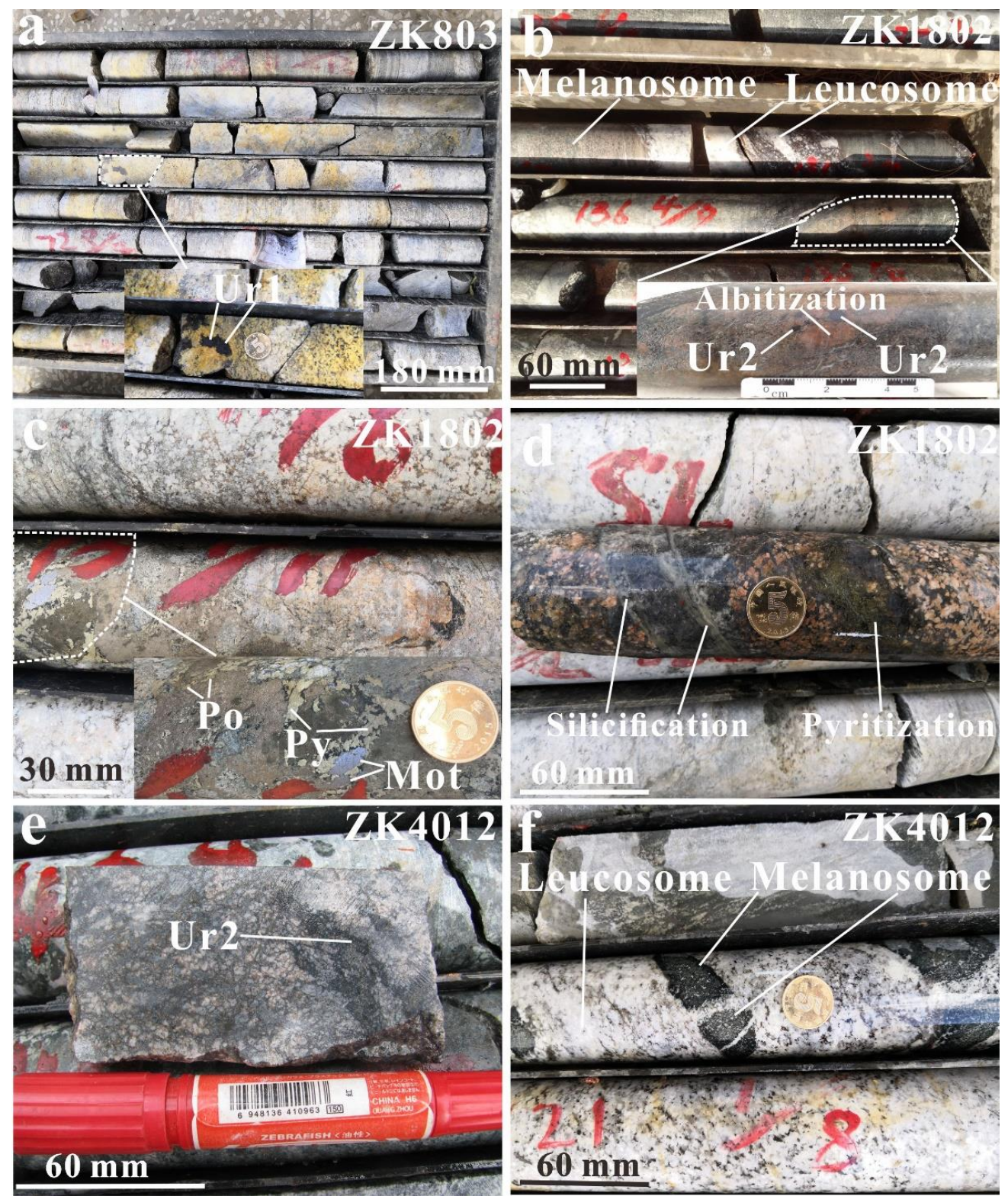

Figure 4. Photos of the drill cores from drill holes ZK803, ZK1802, and ZK4012 in the Datian uranium deposit. (a,b,e) Uraninite hosted in biotite plagioclase migmatite; (c) pyrite, pyrrhotite, and molybdenite in drill hole ZK1802; (d) pyritization and silicification in drill hole ZK1802; (f) biotite plagioclase migmatite in drill hole ZK4012. Mineral abbreviations: Ur-uraninite; Po—pyrrhotite; Py—pyrite; Mot—molybdenite. 

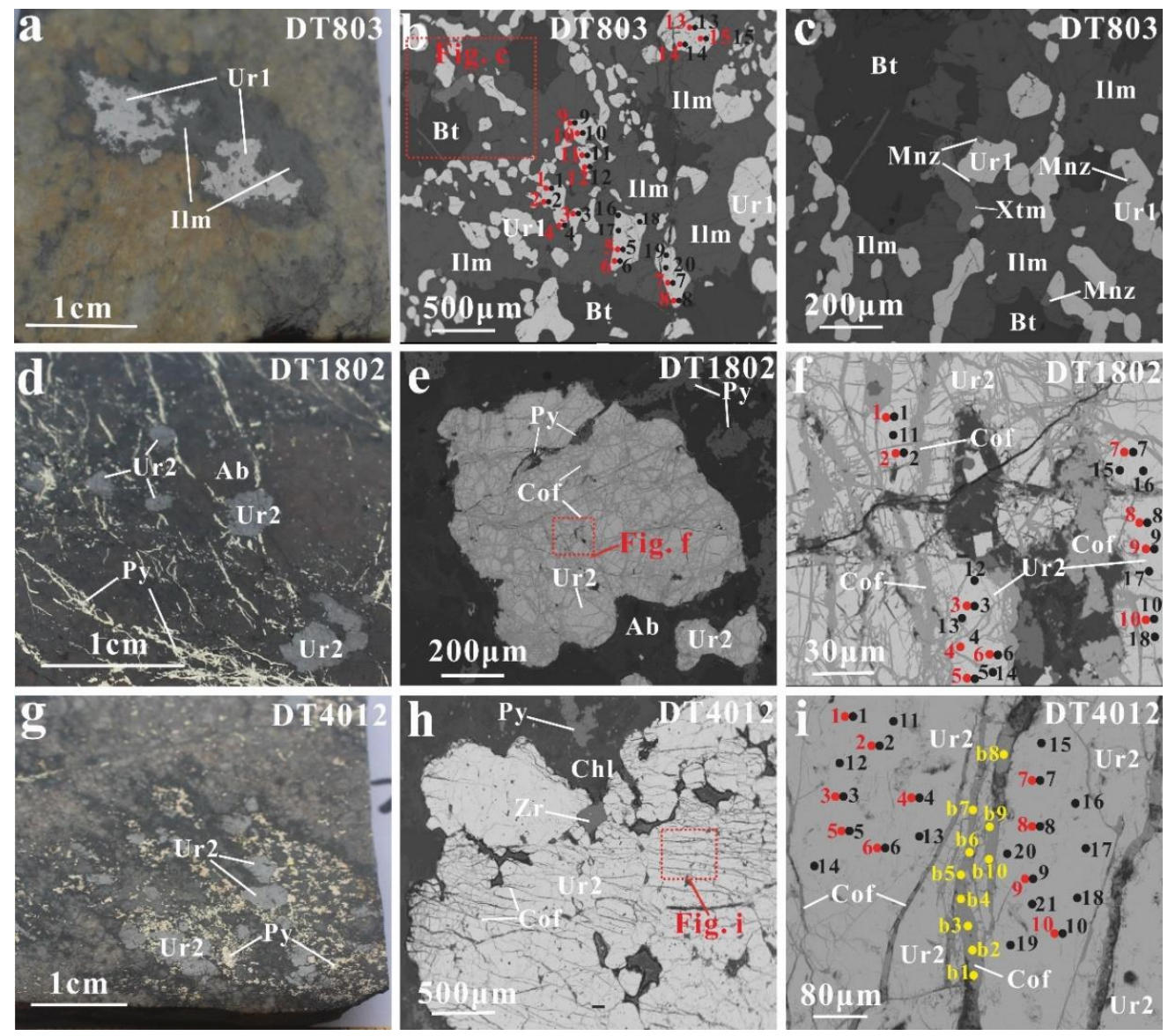

Figure 5. (a,d,g) Polished thin section photos and (b,c,e,f,h,i) backscattered electron (BSE) images showing the uraninite and associated minerals: (a) Ur1 uraninite associated with ilmenite; (b) Ur1 uraninite with a scattered distribution in ilmenite; (c) Ur1 uraninite associated with xenotime, monazite, and ilmenite; (d) Ur2 uraninite associated with albite and granular and veined pyrite; (e) coffinite filling cracks in the Ur2 uraninite, forming a network of veins; (f) dendritic coffinite in the Ur2 uraninite; (g) Ur2 uraninite associated with granular pyrite; (h) Ur2 uraninite associated with zircon, chlorite, and pyrite; (i) fine-grained coffinite filling the fissures in the Ur2 uraninite. Mineral abbreviations: Ur-uraninite; Cof-coffinite; $\mathrm{Py}$-pyrite; $\mathrm{Ab}$-albite; Ilm-ilmenite; Bt-biotite; Xtm-xenotime; Mnz-monazite; $\mathrm{Zr}$-zircon; Chl一chlorite. The red circles indicate the locations of the EMPA spots on the uraninite. The black circles indicate the locations of the LA-ICP-MC spots on the uraninite. The yellow circles indicate the locations of the LA-ICP-MC and EMPA spots on the coffinite.

\subsection{LA-ICP-MS Uraninite U-Pb Ages}

On the basis of the EMPA analyses, the U-Pb isotopes, trace elements, and rare earth elements (REEs) were analyzed at the same or adjacent positions. The U-Pb isotopes, trace elements, and REEs of the uraninite were analyzed at the Beijing Research Institute of Uranium Geology (Beijing, China) by use of LA-ICP-MS (ELEMENT XR, ThermoFisher Scientific, Waltham, MA, USA). The laser was a Geolas $193 \mathrm{~nm}$ excimer laser produced by Coherent Company in the United States with a wavelength of $193 \mathrm{~nm}$. He was used as the carrier gas and Ar was used as the compensation gas. Before testing, the gas flow and working parameters of the ICP-MS were optimized by use of US National Standard Reference Material SRM 610 to achieve the maximum ${ }^{238} \mathrm{U}$ signal strength, a signal intensity ratio of ${ }^{238} \mathrm{U}$ to ${ }^{232} \mathrm{Th}$ of about 1 , an oxide yield (ThO/Th) of less than $0.3 \%$, and a double charge yield $\left(\mathrm{Ca}^{2+} / \mathrm{Ca}^{+}\right)$of less than $0.5 \%$. The laser strip beam spot diameter was $10 \mu \mathrm{m}$, the frequency was $2 \mathrm{~Hz}$, and the energy density was $6 \mathrm{~J} / \mathrm{cm}^{2}$. The U-Pb isotopic ages were calibrated by use of standard uraninite substance GBW04420 (ID-TIMS date of 
$69.8 \pm 0.42 \mathrm{Ma}$ ) developed by the Beijing Research Institute of Uranium Geology [31,32]. GBW04420 is granite type uraninite, which is gray black granular, and the grain size is mainly tens of microns. After crushing, magnetic separation and careful hand-picking, the purity of the GBW04420 is up to $99.8 \%$ [32]. The contents of $\mathrm{U}$ and $\mathrm{Pb}$ in GBW04420 are $69.48 \pm 0.34 \%$ and $6869 \mathrm{ppm}$ respectively, and the atomic percentages of radiogenic ${ }^{206} \mathrm{~Pb}$ and ${ }^{207} \mathrm{~Pb}$ are $94.60 \pm 0.13 \%$ and $4.643 \pm 0.008 \%$ respectively [31]. The calculated ${ }^{206} \mathrm{~Pb} /{ }^{238} \mathrm{U},{ }^{207} \mathrm{~Pb} /{ }^{206} \mathrm{~Pb}$, and ${ }^{207} \mathrm{~Pb} /{ }^{235} \mathrm{U}$ ratios of GBW04420 are $0.01091 \pm 0.00006(1 \sigma)$, $0.05060 \pm 0.00036(1 \sigma)$, and $0.07612 \pm 0.00065(1 \sigma)$ [32]. The GSG (ID-TIMS date of 405-418 Ma; LA-ICP-MS date of $405 \pm 3 \mathrm{Ma}$; EMPA U-Th-Pb date of 407.6-416.9 Ma) is also analyzed to monitor and verify the accuracy of dating results [33-35]. The GSG uraninite sample comes from Guangshigou pegmatite-type uranium deposit in North Qinling orogenic belt, China [36]. The chemical composition and U-Pb age of GSG uraninite are generally homogeneous, and the $\mathrm{U}-\mathrm{Pb}$ system is closed, which can be used as secondary reference material. The GBW04420 and GSG was analyzed twice intercalated with every 6 unknown analyses. The element contents of the uranium minerals were corrected by use of US national standard reference substance SRM 610 and United States Geological Survey (USGS) standard substances BHVO-2G, BCR-2G, and BIR-1G (external standard) [37,38]. The signal acquisition time of each sample was $100 \mathrm{~s}$. Finally, the sample data were processed by use of Data Cal [37], and the age calculations and union drawing were done by use of Isoplot 3.0 [39].

\section{Results}

\subsection{Mineral Assemblages of Uraninite}

Two uranium minerals, uraninite and coffinite, were identified in the three samples. According to their relationships with other minerals and the field relationships, two phases of uraninite were identified. The phase 1 (Ur1) uraninite was found in sample DT803, and the phase 2 (Ur2) uraninite was found in samples DT1802 and DT4012 (Figure 5). The Ur1 uraninite is characterized by local development of microfractures and pores, distinct variations in crystal size, a scattered distribution, and irregular crystal shapes (Figure 5a-c).

The Ur1 uraninite is associated with ilmenite, biotite, and a small amount of monazite and xenotime, with almost no associated pyrite and hardly any coffinite (Figure $5 \mathrm{a}-\mathrm{c}$ ). However, the Ur2 uraninite is associated with pyrite, pyrrhotite, molybdenite (Figure 4c), albite, coffinite, zircon, and chlorite, and it exhibits an especially close relationship with pyrite and albite (Figure $5 d, g$ ). The biggest difference between the Ur1 and Ur2 uraninite is whether they are associated with pyrite (Figure $5 \mathrm{a}, \mathrm{d}, \mathrm{g}$ ). The Ur2 uraninite is mainly controlled by tectonic alteration zones and is distributed in the albitization, silicification, pyritization, and chloritization alteration zones (Figure $4 \mathrm{~b}, \mathrm{~d}$ ). Compared to the Ur2 uraninite, the Ur1 uraninite is less abundant and is mainly distributed in the felsic veins (leucosome) (Figure 4a).

\subsection{Compositions of the Uraninite and Coffinite}

The $\mathrm{ThO}_{2}$ and $\mathrm{Y}_{2} \mathrm{O}_{3}$ contents are significantly different in the Ur1 and Ur2 uraninite (Figure 6). The results are presented in Table $1 . \mathrm{The}_{2} \mathrm{UO}_{2}$ contents of the $\mathrm{Ur} 2$ uraninite range from 79.61 to $82.69 \mathrm{wt} \%$; the $\mathrm{ThO}_{2}$ contents range from 3.41 to $4.83 \mathrm{wt} \%$; and the $\mathrm{Y}_{2} \mathrm{O}_{3}$ contents range from 0.46 to $0.98 \mathrm{wt} \%$. Compared to the Ur2 uraninite, the Ur1 uraninite has higher $\mathrm{UO}_{2}$ contents (81.27-86.45 wt \%), lower $\mathrm{ThO}_{2}$ contents (1.08-1.68 wt \%), and significantly higher $\mathrm{Y}_{2} \mathrm{O}_{3}$ contents (1.11-1.66 wt \%). In addition to $\mathrm{UO}_{2}, \mathrm{Y}_{2} \mathrm{O}_{3}$, and $\mathrm{ThO}_{2}$, the Ur1 and $\mathrm{Ur} 2$ uraninite also have significant $\mathrm{PbO}(7.40-9.89 \mathrm{wt} \%)$. In addition, minor amounts of $\mathrm{SiO}_{2}$ (bdl-0.49 wt \%), $\mathrm{K}_{2} \mathrm{O}(0.11-0.22 \mathrm{wt} \%), \mathrm{Na}_{2} \mathrm{O}$ (bdl-0.16 wt \%), $\mathrm{FeO}$ (bdl-0.25 wt \%), and $\mathrm{CaO}$ (bdl-0.69 wt \%) were also detected in the uraninite grains (bdl, below detection limit). Compared to the uraninite, the coffinite has lower $\mathrm{UO}_{2}(47.24-68.02 \mathrm{wt} \%$,) and $\mathrm{PbO}$ (bdl-2.81 wt \%) contents and far higher $\mathrm{SiO}_{2}(14.08-19.76 \mathrm{wt} \%)$ and $\mathrm{CaO}(0.23-6.1 \mathrm{wt} \%)$ contents in sample DT4012. The results of the EMPA analyses show that the total oxide 
contents of the coffinite are low (minimum of $81.43 \mathrm{wt} \%$ ) because the coffinite contains more water molecules [40].

Overall, the uraninite grains in sample DT803 (Ur1) exhibit the same basic grey shades in the BSE images and X-ray element maps, indicating the homogeneity of the $\mathrm{U}, \mathrm{Pb}$, and Th distributions (Figure 7). In sample DT1802 (Ur2), the uraninite exhibits different grey shades in the BSE images and X-ray element maps, indicating the heterogeneity of the $U$, $\mathrm{Pb}$, and Th distributions (Figure 8). In sample DT1802 (Ur2), fractures, pores, and coffinite are developed in the uraninite (Figure 8a). The BSE images show that the fractures and pores are particularly dark, and the light gray coffinite is distributed in the uraninite as a network of veins. Although the X-ray element maps do not show distinct compositional zoning in sample DT1802, significant depletion of $U$ and Th and enrichment of $\mathrm{Pb}$ was observed in the fractures and pores (Figure $8 \mathrm{~b}-\mathrm{d}$ ). It cannot be confirmed whether the irregularly distributed fractures and pores are the result of radiation damage due to the increased contents of radioactive elements or whether they are fluid-induced dissolution cavities [41]. The widely distributed microfractures in the uraninite in sample DT1802 act as a fluid conduits, which promoted post-mineralization alteration. Based on the above facts, we believe that the coffinite in sample DT1802 is the product of alteration of the uraninite. In sample DT803 (Ur1), a small number of microfractures and pores developed, and coffinite is rare (Figure 7a).
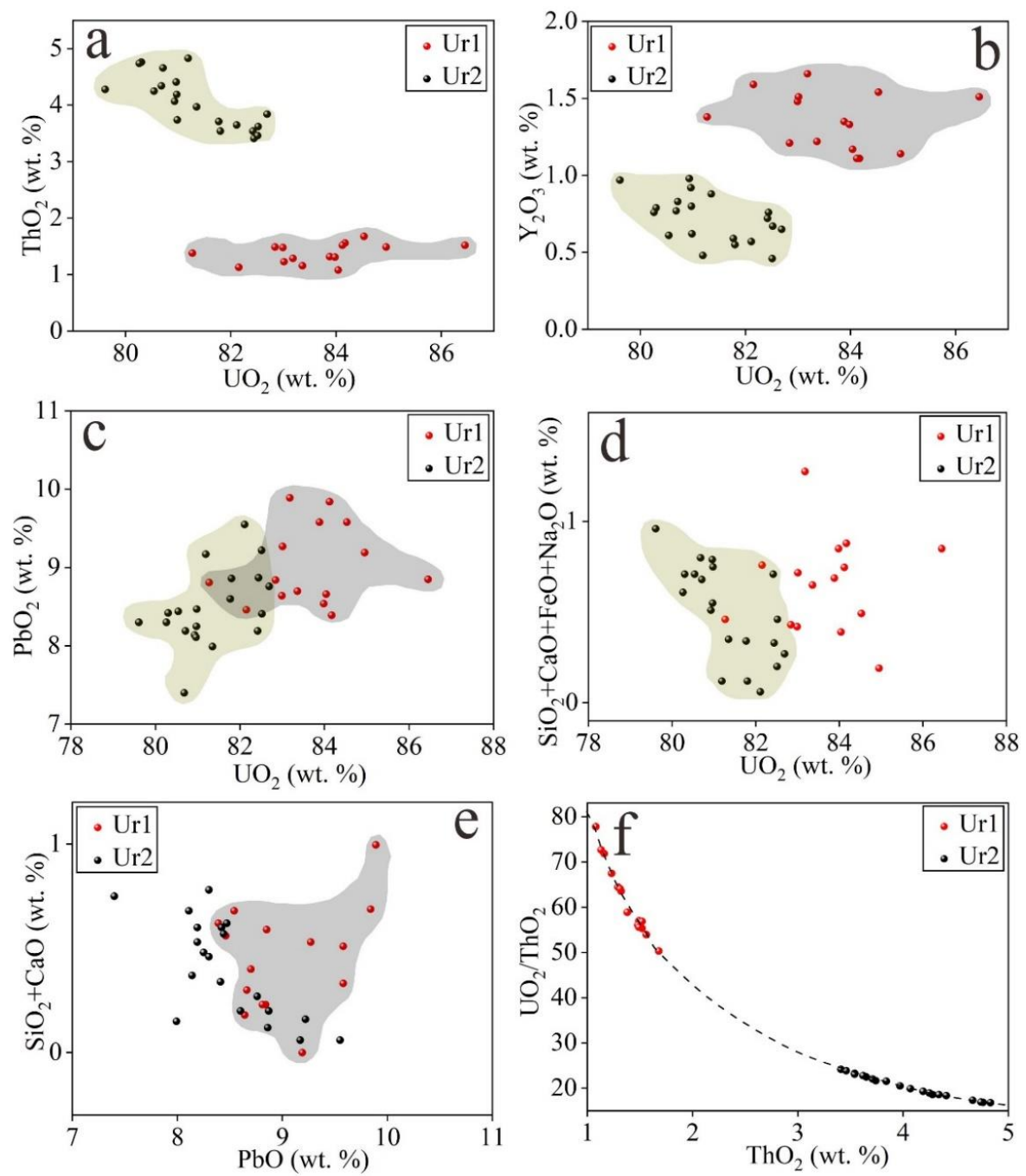

Figure 6. (a-f) Contents of the different major and minor elements in the Ur1 and Ur2 uraninite grains. 
Table 1. Oxide concentrations (wt \%) of uraninite and coffinite from the Datian uranium deposit.

\begin{tabular}{|c|c|c|c|c|c|c|c|c|c|c|c|c|c|c|c|c|c|}
\hline $\begin{array}{c}\text { Sample/EMPA } \\
\text { Spot ID }\end{array}$ & Phase & $\mathrm{UO}_{2}$ & $\mathrm{PbO}$ & $\mathrm{ThO}_{2}$ & $\mathrm{Y}_{2} \mathrm{O}_{3}$ & $\mathrm{SiO}_{2}$ & $\mathrm{~K}_{2} \mathrm{O}$ & MgO & $\mathrm{Ce}_{2} \mathrm{O}_{3}$ & $\mathrm{Na}_{2} \mathrm{O}$ & $\mathrm{FeO}$ & $\mathrm{CaO}$ & $\mathrm{La}_{2} \mathrm{O}_{3}$ & $\mathrm{Nd}_{2} \mathrm{O}_{3}$ & $\mathrm{Pr}_{2} \mathrm{O}_{3}$ & Total & $\mathrm{U} / \mathrm{Th}$ \\
\hline DT803/1 & Ur1 & 84.95 & 9.19 & 1.49 & 1.14 & b.d.l. & 0.15 & 0.02 & b.d.l. & 0.09 & 0.10 & b.d.l. & b.d.l. & 0.37 & b.d.l. & 97.50 & 44.17 \\
\hline DT803/2 & Ur1 & 83.36 & 8.70 & 1.16 & 1.22 & 0.24 & 0.15 & 0.03 & 0.14 & 0.11 & 0.14 & 0.16 & b.d.l. & 0.16 & b.d.l. & 95.57 & 55.67 \\
\hline DT $803 / 3$ & Ur1 & 84.17 & 8.39 & 1.56 & 1.11 & 0.28 & 0.11 & b.d.l. & b.d.l. & 0.10 & 0.16 & 0.34 & b.d.l. & 0.12 & 0.06 & 96.40 & 41.80 \\
\hline DT803/4 & Ur1 & 86.45 & 8.85 & 1.52 & 1.51 & 0.20 & 0.15 & b.d.l. & 0.14 & 0.13 & 0.13 & 0.39 & b.d.l. & 0.10 & b.d.l. & 99.57 & 44.06 \\
\hline DT803/5 & Ur1 & 82.99 & 8.64 & 1.48 & 1.48 & 0.11 & 0.19 & 0.02 & b.d.l. & 0.13 & 0.11 & 0.07 & b.d.l. & 0.16 & b.d.l. & 95.38 & 43.44 \\
\hline DT803/6 & Ur1 & 84.53 & 9.58 & 1.68 & 1.54 & 0.21 & 0.14 & 0.01 & b.d.l. & 0.08 & 0.08 & 0.12 & b.d.l. & 0.31 & 0.04 & 98.32 & 39.00 \\
\hline DT803/7 & Ur1 & 83.88 & 9.58 & 1.32 & 1.35 & 0.20 & 0.14 & b.d.l. & 0.23 & 0.10 & 0.08 & 0.32 & b.d.l. & 0.47 & b.d.l. & 97.66 & 49.23 \\
\hline DT $803 / 8$ & Ur1 & 84.12 & 9.84 & 1.52 & 1.11 & 0.13 & 0.16 & 0.03 & 0.12 & b.d.l. & 0.06 & 0.56 & 0.20 & 0.33 & b.d.l. & 98.18 & 42.88 \\
\hline DT803/9 & Ur1 & 83.18 & 9.89 & 1.29 & 1.66 & 0.37 & 0.13 & 0.03 & b.d.l. & 0.03 & 0.25 & 0.63 & b.d.l. & 0.15 & b.d.l. & 97.60 & 49.96 \\
\hline DT803/10 & Ur1 & 82.15 & 8.46 & 1.13 & 1.59 & 0.39 & 0.11 & 0.02 & 0.24 & 0.09 & 0.11 & 0.17 & 0.07 & 0.13 & 0.03 & 94.69 & 56.32 \\
\hline DT803/11 & Ur1 & 84.04 & 8.66 & 1.08 & 1.17 & 0.16 & 0.18 & b.d.l. & 0.17 & 0.03 & 0.06 & 0.14 & 0.03 & 0.21 & 0.05 & 95.98 & 60.29 \\
\hline DT803/12 & Ur1 & 82.84 & 8.84 & 1.49 & 1.21 & 0.13 & 0.19 & 0.01 & 0.15 & 0.13 & 0.07 & 0.10 & b.d.l. & 0.45 & b.d.l. & 95.61 & 43.07 \\
\hline DT $803 / 13$ & Ur1 & 83.01 & 9.27 & 1.23 & 1.51 & 0.42 & 0.22 & b.d.l. & 0.14 & 0.02 & 0.17 & 0.11 & b.d.l. & 0.34 & b.d.l. & 96.44 & 52.28 \\
\hline DT803/14 & Ur1 & 83.98 & 8.54 & 1.31 & 1.33 & 0.49 & 0.16 & b.d.l. & b.d.l. & 0.08 & 0.09 & 0.19 & b.d.l. & 0.33 & 0.06 & 96.56 & 49.67 \\
\hline DT803/15 & Ur1 & 81.27 & 8.81 & 1.38 & 1.38 & 0.05 & 0.14 & b.d.l. & 0.15 & 0.10 & 0.13 & 0.18 & b.d.l. & 0.38 & b.d.l. & 93.97 & 45.62 \\
\hline DT1802/1 & Ur2 & 82.42 & 8.19 & 3.54 & 0.72 & 0.11 & 0.20 & b.d.l. & 0.54 & 0.06 & 0.05 & 0.49 & b.d.l. & 0.64 & 0.08 & 97.04 & 18.04 \\
\hline DT1802/2 & Ur2 & 80.98 & 8.47 & 3.74 & 0.62 & 0.08 & 0.13 & 0.04 & 0.24 & 0.06 & 0.07 & 0.54 & b.d.l. & 0.47 & 0.08 & 95.52 & 16.77 \\
\hline DT1802/3 & Ur2 & 81.35 & 7.99 & 3.97 & 0.88 & b.d.l. & 0.18 & b.d.l. & 0.76 & 0.16 & 0.04 & 0.15 & 0.16 & 0.44 & 0.05 & 96.13 & 15.88 \\
\hline DT1802/4 & Ur2 & 82.44 & 8.87 & 3.41 & 0.76 & 0.08 & 0.20 & b.d.l. & 0.58 & 0.09 & 0.04 & 0.12 & b.d.l. & 0.31 & 0.06 & 96.96 & 18.73 \\
\hline DT1802/5 & Ur2 & 81.80 & 8.86 & 3.54 & 0.55 & b.d.l. & 0.18 & 0.04 & 0.63 & b.d.l. & b.d.l. & 0.12 & b.d.l. & 0.40 & b.d.l. & 96.12 & 17.90 \\
\hline DT1802/6 & Ur2 & 82.51 & 9.22 & 3.46 & 0.46 & b.d.l. & 0.14 & b.d.l. & 0.55 & 0.04 & b.d.1. & 0.16 & b.d.l. & 0.47 & 0.03 & 97.04 & 18.47 \\
\hline DT1802/7 & Ur2 & 82.11 & 9.55 & 3.65 & 0.57 & b.d.l. & 0.16 & b.d.l. & 0.48 & b.d.l. & b.d.l. & 0.06 & 0.07 & 0.29 & b.d.l. & 96.94 & 17.43 \\
\hline DT1802/8 & Ur2 & 81.77 & 8.60 & 3.71 & 0.59 & 0.06 & 0.17 & b.d.l. & 0.38 & 0.08 & 0.06 & 0.14 & b.d.l. & 0.22 & 0.04 & 95.82 & 17.08 \\
\hline DT1802/9 & Ur2 & 82.52 & 8.41 & 3.62 & 0.67 & 0.07 & 0.27 & b.d.l. & 0.47 & 0.07 & 0.05 & 0.27 & b.d.l. & 0.37 & 0.05 & 96.84 & 17.66 \\
\hline DT1802/10 & Ur2 & 82.69 & 8.76 & 3.84 & 0.65 & b.d.l. & 0.23 & 0.03 & 0.73 & b.d.l. & b.d.l. & 0.27 & b.d.l. & 0.47 & b.d.l. & 97.67 & 16.68 \\
\hline DT4102/1 & Ur2 & 80.93 & 8.14 & 4.07 & 0.98 & b.d.l. & 0.18 & 0.03 & 0.51 & 0.10 & 0.04 & 0.37 & b.d.l. & 0.25 & 0.04 & 95.64 & 15.41 \\
\hline DT4102/2 & Ur2 & 80.97 & 8.25 & 4.19 & 0.80 & 0.09 & 0.12 & b.d.l. & 0.34 & 0.07 & b.d.l. & 0.39 & 0.10 & 0.27 & b.d.l. & 95.59 & 14.97 \\
\hline DT4102/3 & Un2 & 79.61 & 8.30 & 4.28 & 0.97 & 0.19 & 0.14 & b.d.l. & 0.34 & 0.09 & 0.09 & 0.59 & 0.07 & 0.39 & 0.03 & 95.09 & 14.41 \\
\hline DT4102/4 & Ur2 & 80.71 & 8.19 & 4.66 & 0.83 & 0.06 & 0.21 & 0.02 & 0.36 & 0.15 & b.d.l. & 0.47 & 0.16 & 0.21 & b.d.l. & 96.03 & 13.42 \\
\hline DT4102/5 & Ur2 & 81.19 & 9.17 & 4.83 & 0.48 & b.d.l. & 0.14 & b.d.l. & 0.51 & 0.06 & b.d.l. & 0.06 & b.d.l. & 0.27 & 0.09 & 96.80 & 13.02 \\
\hline DT4102/6 & Ur2 & 80.68 & 7.40 & 4.34 & 0.77 & 0.06 & 0.22 & b.d.l. & 0.30 & b.d.l. & 0.05 & 0.69 & 0.09 & 0.24 & b.d.l. & 94.84 & 14.40 \\
\hline DT4102/7 & Ur2 & 80.30 & 8.42 & 4.76 & 0.79 & 0.08 & 0.18 & 0.02 & 0.59 & 0.11 & b.d.l. & 0.52 & b.d.l. & 0.31 & 0.05 & 96.13 & 13.07 \\
\hline DT4102/8 & Un2 & 80.96 & 8.11 & 4.41 & 0.92 & 0.09 & 0.19 & b.d.l. & 0.87 & 0.11 & b.d.l. & 0.59 & 0.13 & 0.45 & 0.05 & 96.88 & 14.22 \\
\hline DT4102/9 & Ur2 & 80.54 & 8.44 & 4.25 & 0.61 & 0.06 & 0.19 & 0.04 & 0.37 & 0.14 & b.d.l. & 0.51 & 0.14 & 0.36 & 0.06 & 95.71 & 14.68 \\
\hline DT4102/10 & Ur2 & 80.26 & 8.30 & 4.74 & 0.76 & 0.07 & 0.16 & 0.02 & 0.62 & 0.15 & b.d.l. & 0.39 & 0.12 & 0.27 & 0.07 & 95.93 & 13.12 \\
\hline DT4102/b1 & Ur2C & 47.24 & 0.12 & 0.74 & 13.77 & 17.46 & 0.16 & 0.02 & 0.62 & b.d.l. & 0.23 & 0.23 & 0.14 & 0.64 & 0.06 & 81.43 & 41.75 \\
\hline DT4102/b2 & Ur2C & 58.92 & 0.45 & 2.57 & 0.50 & 18.72 & 0.12 & 0.05 & 0.52 & b.d.l. & 0.46 & 0.90 & 0.09 & 0.16 & 0.05 & 83.51 & 14.99 \\
\hline DT4102/b3 & Ur2C & 61.24 & 0.45 & 1.97 & 0.36 & 19.66 & 0.22 & 0.03 & 0.29 & 0.03 & 0.87 & 1.00 & b.d.l. & b.d.l. & 0.05 & 86.17 & 20.33 \\
\hline DT4102/b4 & Ur2C & 56.08 & 0.90 & 5.22 & 0.51 & 19.33 & 0.24 & b.d.l. & 1.03 & b.d.l. & 0.31 & 0.75 & 0.15 & 0.51 & 0.03 & 85.06 & 7.03 \\
\hline DT4102/b5 & Ur2C & 59.07 & 0.37 & 4.13 & 0.60 & 18.62 & 0.21 & 0.04 & 0.30 & 0.21 & b.d.l. & 3.29 & b.d.l. & 0.21 & b.d.l. & 87.05 & 9.35 \\
\hline DT4102/b6 & Ur2C & 68.02 & b.d.l. & b.d.l. & b.d.l. & 14.43 & 0.25 & b.d.l. & b.d.l. & b.d.l. & 0.05 & 6.10 & 0.07 & b.d.l. & 0.03 & 88.95 & 0.00 \\
\hline DT4102/b7 & Ur2C & 64.93 & 2.81 & b.d.l. & b.d.l. & 14.08 & 0.22 & 0.03 & 0.13 & b.d.l. & 0.10 & 5.74 & b.d.l. & 0.09 & b.d.l. & 88.13 & 0.00 \\
\hline DT4102/b8 & Ur2C & 61.81 & 0.59 & 2.29 & 0.11 & 19.76 & 0.46 & 0.13 & 0.46 & 0.10 & 1.77 & 2.81 & 0.24 & 0.15 & b.d.l. & 90.68 & 17.65 \\
\hline DT4102/b9 & Ur2C & 62.70 & 0.25 & 2.13 & 0.70 & 15.70 & 0.27 & 0.04 & 0.42 & 0.23 & 0.34 & 4.29 & b.d.l. & 0.32 & b.d.l. & 87.39 & 19.25 \\
\hline DT4102/b10 & Ur2C & 64.60 & 0.80 & 3.21 & 0.46 & 17.88 & 0.34 & 0.06 & 0.27 & 0.16 & 0.54 & 0.85 & 0.12 & 0.21 & 0.02 & 89.52 & 13.16 \\
\hline
\end{tabular}

Note: b.d.l. = below detectable limit; Ur1 = phase 1 uraninite; Ur2 = phase 2 uraninite; Ur2C = phase 2 coffinite.
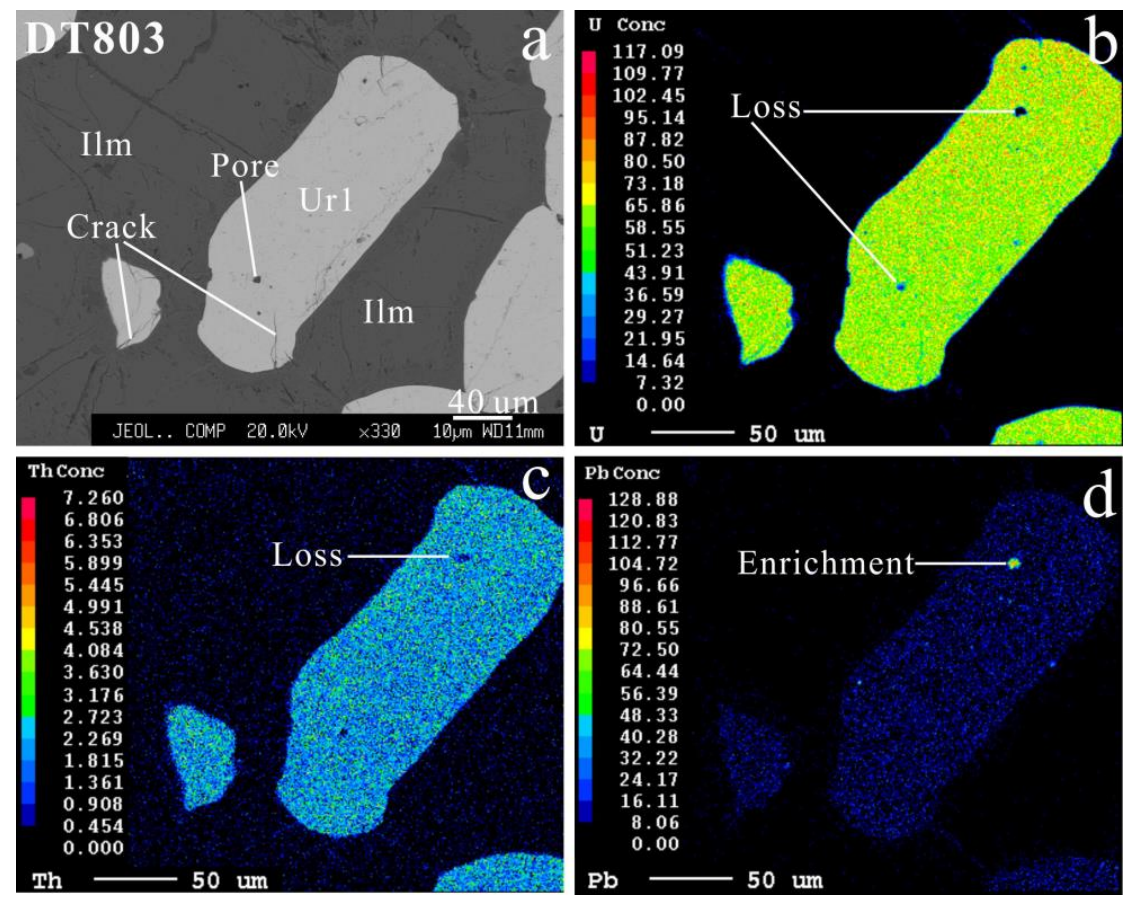

Figure 7. (a) BSE images and (b-d) X-ray element maps of the Ur1 uraninite grains showing intragrain compositional homogeneity. Mineral abbreviations: Ur-uraninite; Ilm-ilmenite. 

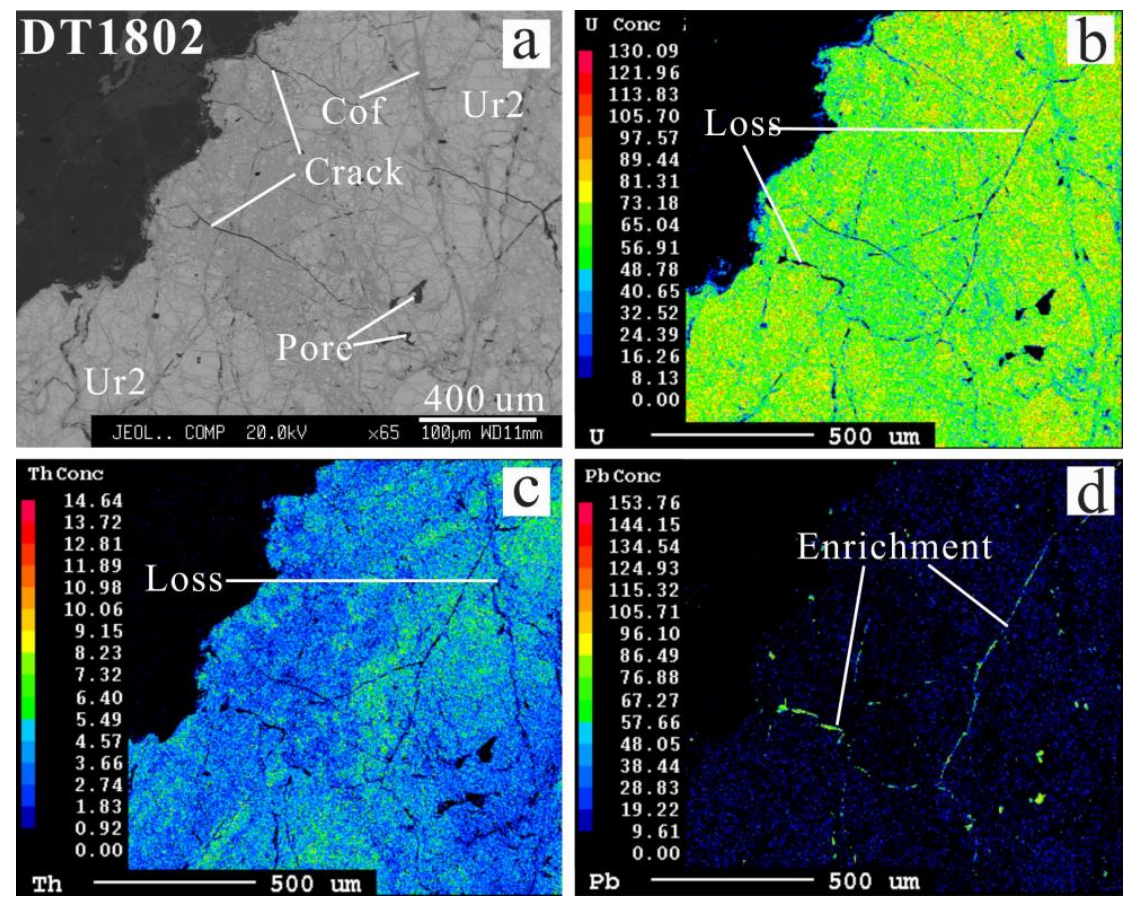

Figure 8. (a) BSE images and (b-d) X-ray element maps of the Ur2 uraninite grains showing intragrain compositional heterogeneity. (b-d) The element maps show that the fractures and pores in the uraninite grain are depleted in $\mathrm{U}$ and $\mathrm{Th}$ and enriched in $\mathrm{Pb}$. Mineral abbreviations: $\mathrm{Ur}$ - uraninite; Cof-coffinite.

\subsection{Trace Element Contents of the Uraninite and Coffinite}

In general, the variations in the trace element concentrations of the Ur1 and Ur2 uraninite are not large (Figure 9 and Table S1). Most of the 31 elements analyzed have contents above the limits of detection (LOD) in the Ur1 and Ur2 uraninite, with the exception of V (bdl-6.5 ppm), Co (bdl-29.0 ppm), Cu (bdl-21.6 ppm), Zn (bdl-110.0 ppm), Ga (bdl-64.7 ppm), Rb (bdl-65.4 ppm), Sr (bdl-17.2 ppm), Nb (bdl-6.3 ppm), Ba (bdl-28.1 ppm), Hf (bdl-3.9 ppm), and Ta (bdl-1.4 ppm). This indicates that these elements have been incorporated into the Ur1 and Ur2 uraninite in different proportions [3]. In sample DT4012 (Ur2), the V (bdl-222.0 ppm), Cu (bdl-87.8 ppm), Zn (bdl-1381.0 ppm), Ga (42.0-306.0 ppm), $\mathrm{Rb}$ (bdl-103.0 ppm), Sr (3.7-412.0 ppm), Nb (bdl-16.1 ppm), Ba (bdl-169.0 ppm), and Hf (bdl-24.6 ppm) contents of the coffinite are significantly higher than those of the uraninite, indicating that these elements replaced $\mathrm{Pb}$ during the formation of the uraninite [3]. 

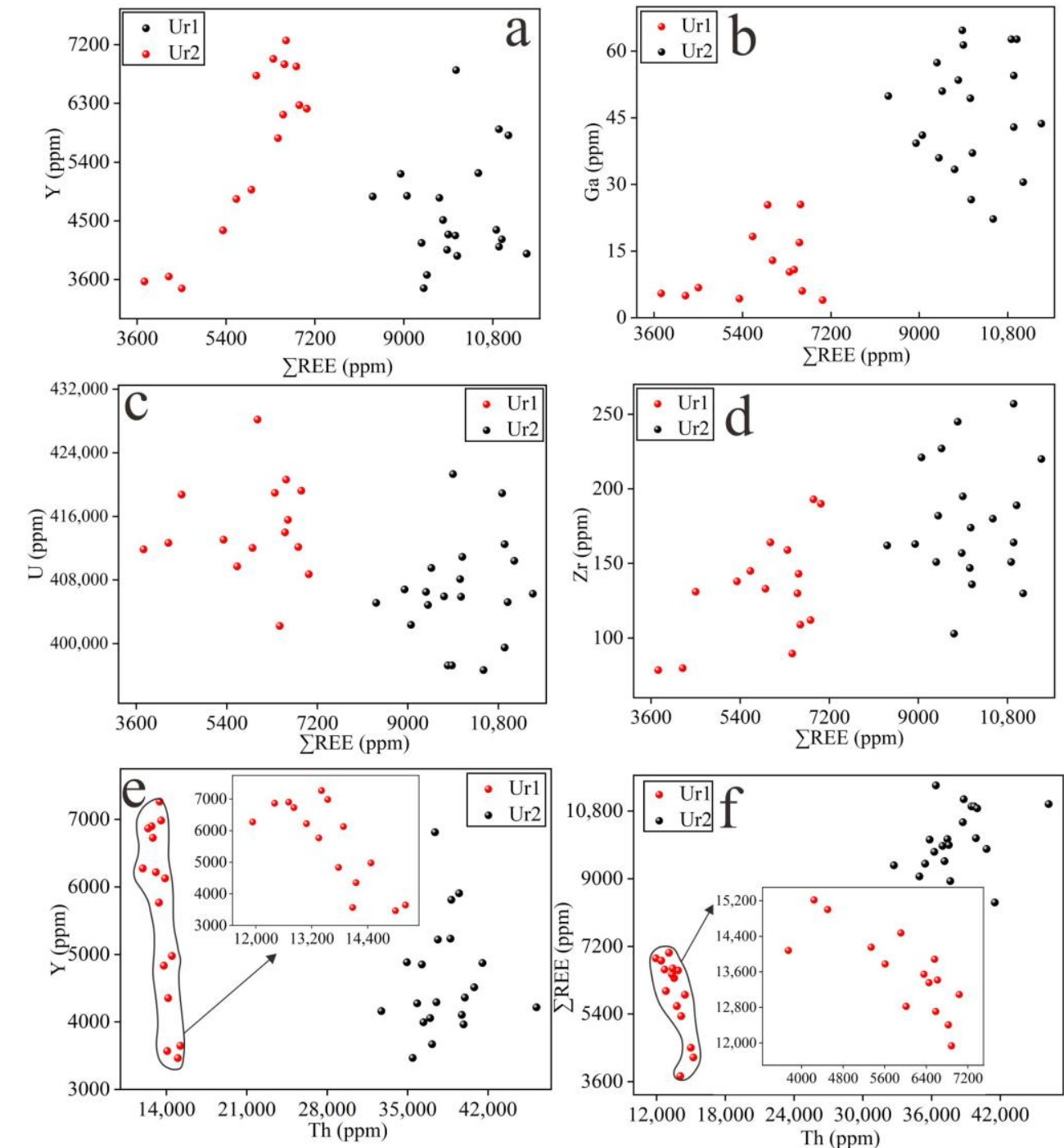

Figure 9. (a-f) Variations in the trace and rare earth element contents of the Ur1 and Ur2 uraninite in the Datian uranium deposit.

\subsection{Rare Earth Element Contents of the Uraninite and Coffinite}

The rare earth element (REE) patterns of the Ur1 and Ur2 uraninite are sickle-shaped, with low light rare earth element (LREE) and heavy rare earth element (HREE) contents compared to the middle rare earth element (MREE) contents (Figure 10a-c). The REE patterns of the Ur1 and Ur2 uraninite exhibit large negative Eu anomalies.

The $\Sigma$ REE (increasing from 9399.6 to $11484.3 \mathrm{ppm}$ and 8369.2 to $11484.3 \mathrm{ppm}$ for samples DT1802 and DT4012, respectively) and $\Sigma$ LREE/ $\Sigma$ HREE ratios (increasing from 1.90 to 2.15 and from 1.05 to 1.84 for samples DT1802 and DT4012, respectively) of samples DT1802 and DT4012 are basically similar (Table S1), with inconspicuously right-sloping REE patterns (Figure 10b,d). Compared to samples DT1802 (Ur2) and DT4012 (Ur2), the $\Sigma$ REE (3747.5-7032.3 ppm) and $\Sigma$ LREE/ $\Sigma$ HREE ratios (0.42-0.53) of sample DT803 (Ur1) are significantly lower. The REE pattern of sample DT803 is left-sloping (Figure 10a) and is significantly different from those of samples DT1802 and DT4012. The $\Sigma$ LREE of the coffinite in sample DT4012 is significantly higher than the $\Sigma$ HREE, with a negative Eu anomaly (Figure 10d). The $\Sigma$ REE of the coffinite is basically the same as that of the uraninite in sample DT4012. Compared to the uraninite, the coffinite exhibits strong fractionation between the LREEs and HREEs ( $\Sigma$ LREE/ $\Sigma$ HREE: 2.22-4.58). 

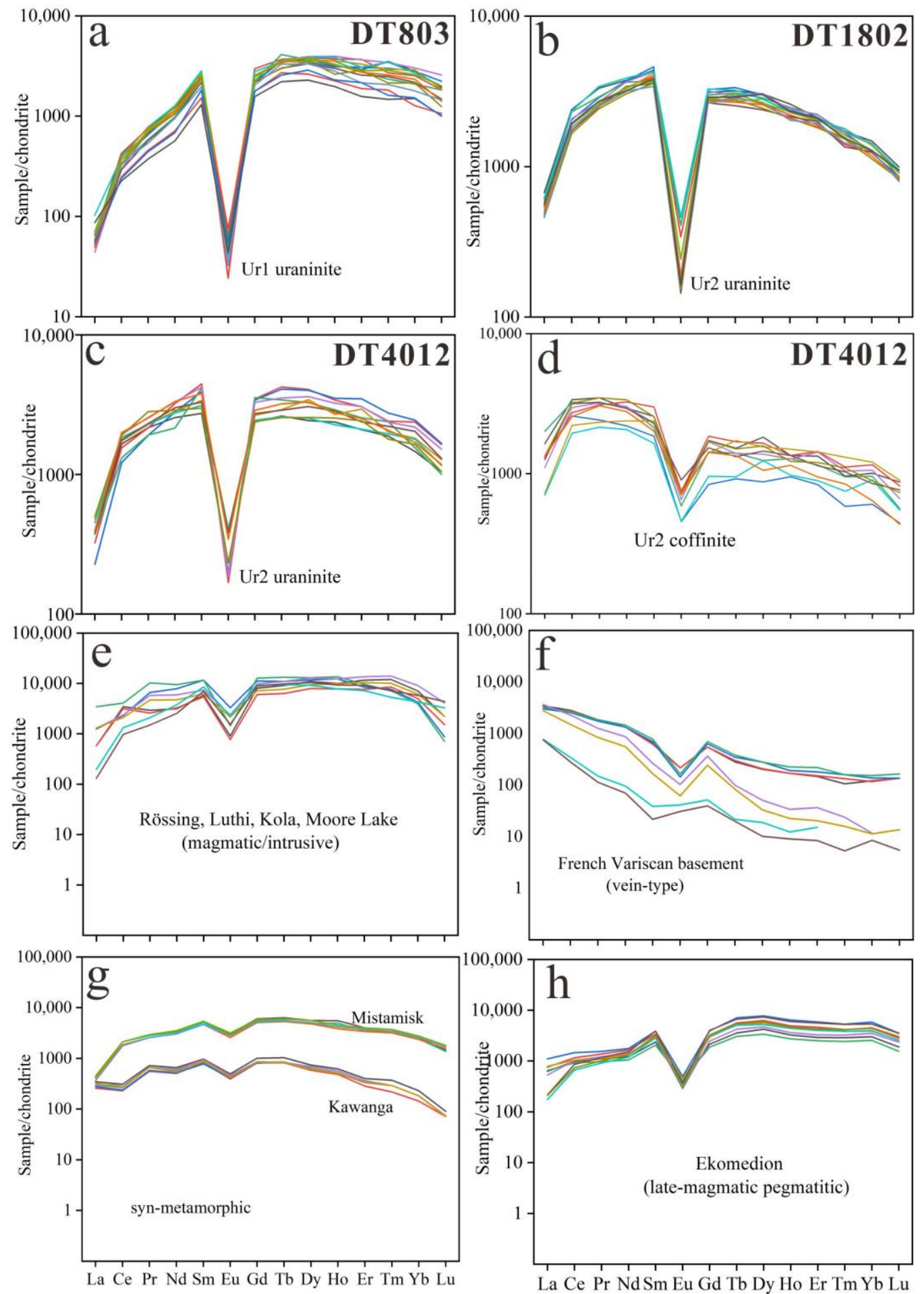

Figure 10. Chondrite-normalized REE patterns of the uraninite and coffinite from the Datian uranium deposit and various hydrothermal and magmatic deposits around the world; $(\mathbf{a}-\mathbf{c})$ REE patterns of the uraninite and (d) REE patterns of the coffinite from this study; (e-g) data from Mercadier et al. [42]; (h) data from Frimmel et al. [43]; LREEs are from La to Eu and HREEs are from Gd to Lu; normalization values from Anders and Grevesse [44].

\subsection{LA-ICP-MS Uraninite U-Pb Ages}

The $\mathrm{U}-\mathrm{Pb}$ isotopic compositions of the uraninite from the Datian uranium deposit were analyzed via LA-ICP-MS. The results are presented in Table S1. The ages of the uraninite in samples DT803 (Ur1), DT1802 (Ur2), and DT4012 (Ur2) are $841.4 \pm 4.0 \mathrm{Ma}$, 
$837.2 \pm 4.5 \mathrm{Ma}$, and $834.5 \pm 4.1 \mathrm{Ma}$, respectively. The U-Pb isotopic compositions of the uraninite are very homogeneous, showing good consistent uraninite ages on the concordia diagram (Figure 11). Therefore, these three ages can represent the formation ages of the uraninite in the Datian uranium deposit.
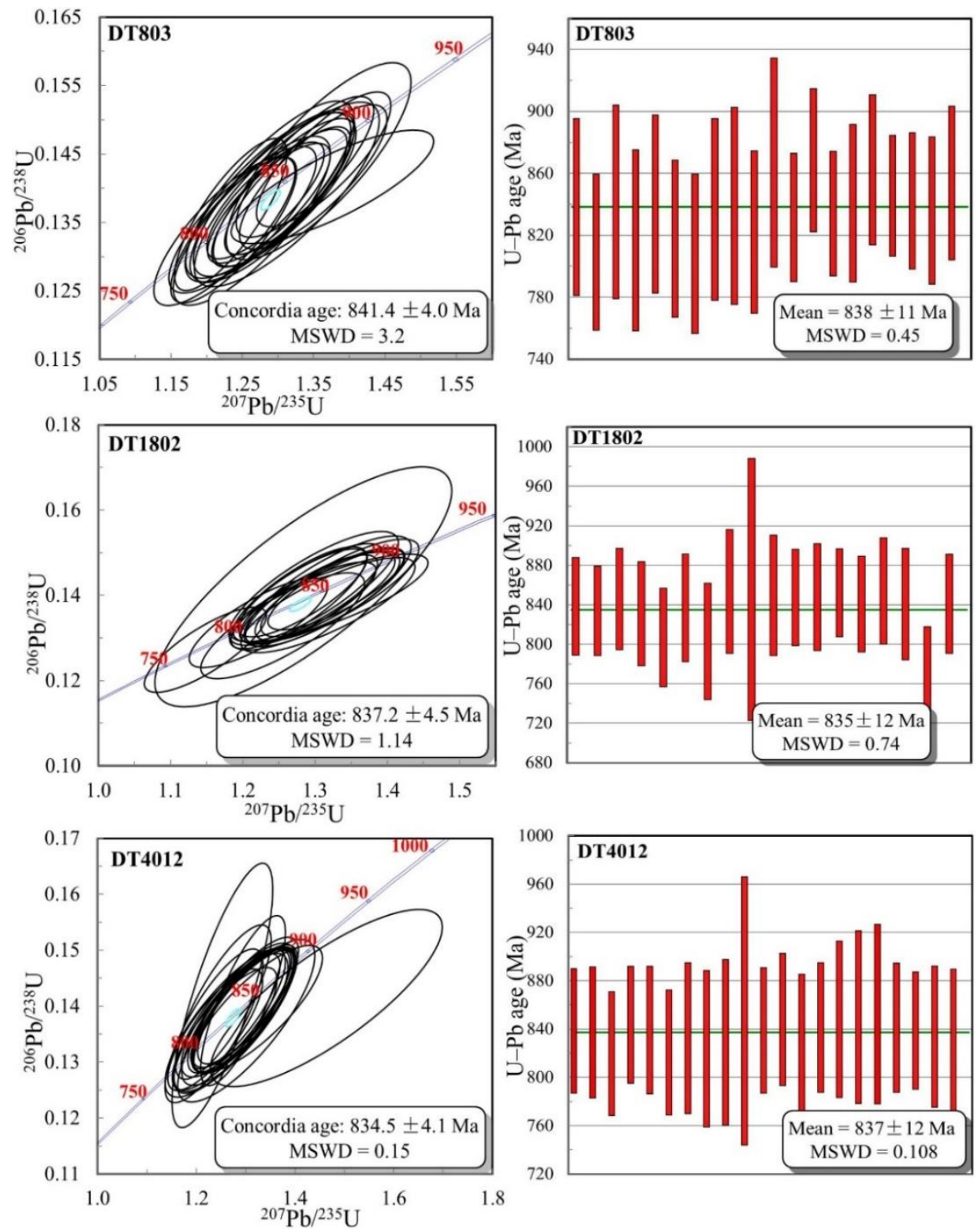

Figure 11. LA-ICP-MS U-Pb concordia diagram of the uraninite and weighted ages of samples DT803 (Ur1), DT1802 (Ur2), and DT4012 (Ur2) from the Datian uranium deposit.

\section{Discussion}

\subsection{Significance of the Major Element Compositions of the Uraninite and Coffinite}

Pure uraninite $\left(\mathrm{U}^{+4} \mathrm{O}_{2}\right)$ is extremely rare in nature owing to the automatic oxidation caused by the radioactive decay of the uranium. The defects and non-stoichiometry of uraninite are conducive to the substitution of cations, resulting in changes in the chemical formula to $\left(\mathrm{U}_{1-\mathrm{x}-\mathrm{y}-\mathrm{z}}^{4+} \mathrm{U}_{\mathrm{x}}^{6+} \mathrm{REE}_{\mathrm{y}}^{3+} \mathrm{M}_{2}^{2+}\right) \mathrm{O}_{2+\mathrm{x}-(0.5 \mathrm{y})-\mathrm{z}}[41,45-47]$. During uraninite crystallization, it is easy for the elements in the uraninite to exchange with those in the hydrothermal fluids [48]. The exchange of uranium with other elements is related to the temperature and ionic radii of the elements [49]. The contents of these elements ( $\mathrm{Th}, \mathrm{Ca}, \mathrm{Si}, \mathrm{Fe}, \mathrm{K}, \mathrm{Al}$, $\mathrm{Na}$, REEs, and $\mathrm{Y}$ ) in the uraninite are a function of the physicochemical conditions (redox state, mineralization temperature, and fluid composition) [42,43,50-52]. 
The $\mathrm{ThO}_{2}$ content of uraninite is an important index used to judge its formation temperature $[43,53]$. When uraninite crystallizes, $\mathrm{Th}^{4+}$ can replace the $\mathrm{U}^{4+}$ in the uraninite because both have atomic radii of $1.1 \AA$ for a coordination number of $8[43,54,55]$. Owing to the low solubility of $\mathrm{Th}^{4+}$, the mobility of Th in the hydrothermal environment is low [43]. Therefore, $\mathrm{Th}^{4+}$ has a high solubility (1-12 wt \% $\mathrm{ThO}_{2}$ ) in high temperature hydrothermal fluids and a low solubility in low temperature hydrothermal fluids $[56,57]$. The high $\mathrm{ThO}_{2}$ content (3.41-4.83 wt \%) of the Ur2 uraninite indicates that it was formed at high temperatures (Figure $6 \mathrm{a})$. The $\mathrm{ThO}_{2}$ content $(1.08-1.68 \mathrm{wt} \%$ ) of the Ur1 uraninite is significantly lower than that of the Ur2 uraninite, which indicates that the Ur1 and Ur2 uraninite formed at different temperatures. The Ur1 uraninite was also formed at high temperatures, but at temperatures lower than that of the Ur2 uraninite. The high $\mathrm{ThO}_{2}$ contents of the Ur1 and Ur2 uraninite indicate that they formed at high temperatures, for instance at temperatures consistent with magmatic hydrothermal, metamorphic, and magmatic processes [41]. This conclusion is further verified by the U/Th versus $\sum R E E$ diagram, on which all of the uraninite data plot within the high temperature magmatic/metamorphic field $\left(>450{ }^{\circ} \mathrm{C}\right.$; Figure 12a). The hyperbolic trend of the data on the $\mathrm{UO}_{2} / \mathrm{ThO}_{2}$ versus $\mathrm{ThO}_{2}$ plot (Figure 6f) shows that $\mathrm{ThO}_{2}$ was incorporated into the structures of the Ur1 and Ur2 uraninite during crystallization from a high temperature hydrothermal fluid $[41,53,58]$. The $\mathrm{CaO}$, $\mathrm{SiO}_{2}, \mathrm{Na}_{2} \mathrm{O}$, and $\mathrm{FeO}$ data of the Ur1 and $\mathrm{Ur} 2$ uraninite are very scattered (Figure 6d,e), indicating that $\mathrm{Ca}, \mathrm{Si}, \mathrm{Na}$, and Fe entered the uraninite structure during crystallization [55]. Most of the Ur1 and Ur2 uraninite are characterized by low $\mathrm{SiO}_{2}$ (bdl-0.49 wt \%) and $\mathrm{FeO}$ (bdl-0.25 wt \%) contents, which indicates that they are fresh and were only slightly influenced by post-crystallization alteration $[59,60]$.
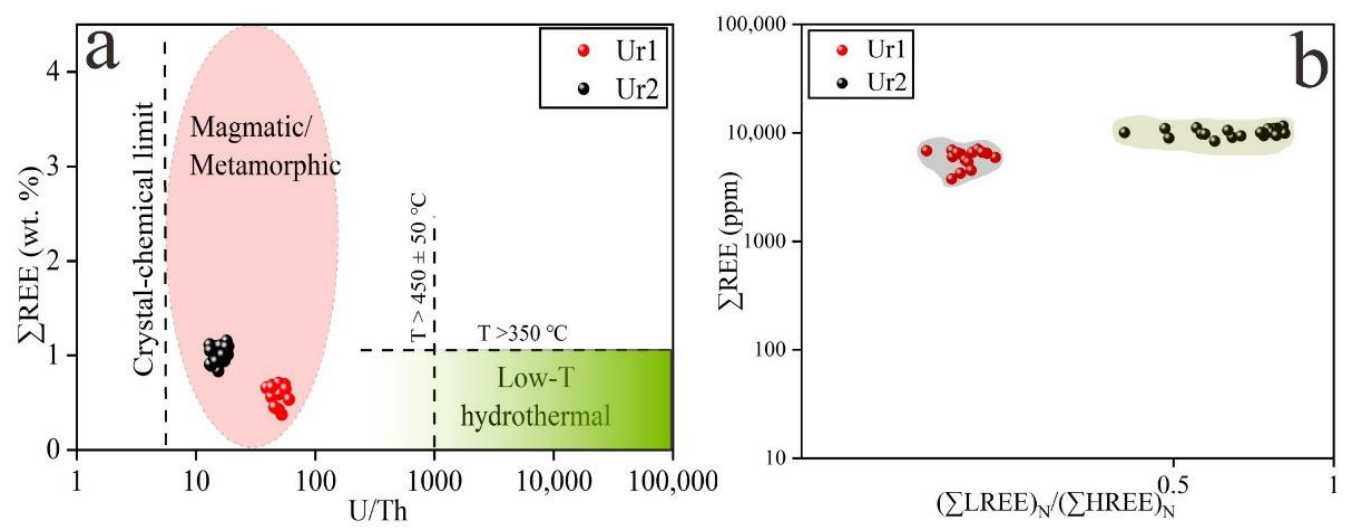

Figure 12. (a) Plot of $\sum R E E$ versus $U / T h$ for the Ur1 and Ur2 uraninite from the Datian uranium deposit [42]. (b) Plot of $\sum$ REE versus LREE (La-Eu)/HREE (Gd-Lu) for the Ur1 and Ur2 uraninite from the Datian uranium deposit [43]. Normalization values from Anders and Grevesse [44].

The enriched Si contents reflect alteration because of the tendency of uraninite to form coffinite [43]. The coffinite filling the fissures in the uraninite is a product of the later alteration of the uraninite. In sample DT4102, the $\mathrm{UO}_{2}$ and $\mathrm{PbO}$ contents of the coffinite are significantly lower than those of the uraninite, but the $\mathrm{SiO}_{2}$ content is much higher. This indicates that the $\mathrm{U}$ and $\mathrm{Pb}$ were mainly exited, and that the Si entered the uraninite during the alteration. During the alteration process, $\mathrm{Si}^{4+}$ easily entered the lattice of the uraninite and a large amount of exchange occurred with $\mathrm{U}^{4+}$, resulting in a sharp increase in the $\mathrm{SiO}_{2}$ content and a decrease in the $\mathrm{UO}_{2}$ content of the coffinite [40]. It is not easy for $\mathrm{Pb}^{4+}$ to enter the uraninite lattice due to the difference in ionic radii of $\mathrm{Pb}^{4+}(1.37 \AA)$ and $\mathrm{U}^{4+}\left(1.08 \AA\right.$ ) $[40,59]$. Therefore, $\mathrm{Pb}^{4+}$ always leaves the uraninite crystal structure during alteration events, resulting in the coffinite having a very low $\mathrm{PbO}$ content. In sample DT4102, the coffinite was formed by later hydrothermal alteration of the uraninite, and the microfractures may have acted as fluid conduits [41]. 


\subsection{Interpretation of the REE Concentrations and Patterns}

It has been proposed that the REE contents of uraninite can be used to determine the geological conditions of the genesis of uranium deposits [3,42,52,61-64]. The variation in the $\sum$ REE of uraninite is controlled by the ore genesis, mineralization temperature, and paragenetic minerals $[42,43]$. The higher the formation temperature of the uraninite is, the greater the $\sum$ REE is $[42,43,55,60]$. The REE pattern of uraninite is mainly governed by the partition coefficients and ore-forming temperature [42,55]. A large amount of REEs are incorporated into uraninite at high temperatures, and the partition coefficients have a weak effect on the REE pattern [55]. In contrast, at low temperatures, the incorporation of REEs into uraninite is difficult and the compatibility of REEs with the crystal structure of uraninite has a significant influence. The Ur1 and Ur2 uraninite were formed at high temperatures, and their REE patterns were mainly controlled by temperature. On the $\sum$ REE versus $\left(\sum \text { LREE }\right)_{\mathrm{N}} /\left(\sum \mathrm{HREE}\right)_{\mathrm{N}}$ diagram (Figure $\left.12 \mathrm{~b}\right)$, the data points plot in different clusters and do not overlap with each other. The Ur1 uraninite exhibits obvious fractionation between LREEs and HREEs, with significantly lower LREE concentrations compared to the HREE concentrations (Figure 10a). This may be caused by the LREEs entering the monazite and forming LREE-rich monazite during the formation of the uraninite [65]. Some monazite was found in the Ur1 uraninite, which supports this conjecture (Figure 5b,c). The negative Eu anomalies of the Ur1 and Ur2 uraninite are larger than those of the pegmatite-type uranium deposit in Ekomédion (Figure 10h) and the magmatic rock-type uranium deposit in Rössing (Figure 10e). This was caused by the fractionation of plagioclase during the migmatization process and the reducing conditions during the precipitation of the uraninite [42]. The ilmenite in the Ur1 uraninite and the pyrite in the Ur2 uraninite indicate that the uraninite formed under reducing conditions [66].

In sample DT4012, the $\sum$ LREE of the coffinite is significantly higher than that of the uraninite and its REE pattern is right-sloping (Figure 10d). Coffinite is mostly formed under medium to low temperature conditions [40]. This indicates that the REE pattern of coffinite is principally controlled by the partition coefficients [43].

The intense negative correlations between Th and Y (Figure 9e) and Th and $\Sigma$ REE (Figure 9f) for the Ur1 uraninite do not indicate that they were not simultaneously incorporated into the Ur1 uraninite, but rather they indicate the different behaviors during the formation of the Ur1 uraninite. Owing to its similar geochemical behavior, $\mathrm{Y}$ tends to have a close relationship with the $\sum$ REE content [43]. The $\sum$ REE content is positively correlated with $Y$ in the Ur1 uraninite (Figure 9a). The intense positive correlation between $\sum R E E$ and $Y$ indicates that they were likely incorporated into the Ur1 uraninite at the same time.

\subsection{Role of Migmatites in the Formation of the Uraninite}

The EMPA U-Th-Pb chemical ages of the uraninite in the Datian uranium deposit were previously reported to be 774.9-785.5 Ma [23]. However, the reliability of these ages is difficult to evaluate because most of the uraninite samples were collected from the surface and were highly weathered. In this study, fresh samples were collected from drill holes for in-situ LA-ICP-MS U-Pb isotopic dating of the uraninite. The ages obtained are very homogeneous, and the $\mathrm{SiO}_{2}$ and $\mathrm{FeO}_{2}$ contents of the uraninite are very low. These facts indicate that the dating results are reliable and were less affected by later alteration. Our results demonstrate that the Ur1 $(841.4 \pm 4.0 \mathrm{Ma})$ and Ur2 $(834.5 \pm 4.1-837.2 \pm 4.5 \mathrm{Ma})$ uraninite from the Datian uranium deposit predated the formation of the granitic dikes (765-778 Ma) by $\sim 65 \mathrm{Ma}$ [21], and thus, they should not have genetic relationship with the granitic dikes. The zircon $\mathrm{U}-\mathrm{Pb}$ ages of the biotite plagioclasite migmatite in the Datian uranium deposit are 830-900 Ma [20]. During the Neoproterozoic, the Yangtze Block was principally in an extensional setting [67], but it was interrupted by the 860-818 Ma Sibao orogeny [68]. This indicates that the migmatites were mainly formed in an orogenic setting.

On the basis of the zircon U-Pb ages of the granitic veins (765-778 Ma) and the EMPA U-Th- $\mathrm{Pb}$ chemical ages of the uraninite (774.9-785.5 Ma) in the Datian uranium deposit, several scholars have concluded that the granitic veins intruded along the structural 
alteration zone (F3; Figure 3) and formed hydrothermal fluids under the background of continental rifting and extension [18,20-22]. The hydrothermal fluids extracted the oreforming materials from the migmatite and transported them into the secondary structural alteration zone (F1, F2, and F4; Figure 3) to form the uraninite [21,23]. Our study clarifies the temporal relationship between the migmatite and uraninite. The temporal consistency shows that the Ur1 and Ur2 uraninite are genetically related to the migmatite. On the basis of our results, we propose a formation process for the Datian uranium deposit. During the orogeny, owing to migmatization, the uranium was remobilized from a primal diagenetic uranium stock within the migmatite or the migmatized gneiss in the Zanli Formation. The uranium transfer was guaranteed by high-temperature hydrothermal fluids produced by the dehydration, degassing, and dissolution reactions during the migmatization [9]. The uranium precipitation was controlled by the secondary structural alteration zone (F1, F2, and F4; Figure 3) and occurred adjacent to reducing agents such as sulfides and graphites. REE fractionation patterns are a reliable discriminator between different genetic types [43]. The REE patterns of the uraninite in the Datian uranium deposit are significantly different from those of magmatic/intrusive type, hydrothermal vein type, synmetamorphic type, and late magmatic pegmatite type uraninite around the world (Figure 10), indicating that a genetic difference between the Datian uranium deposits and these uranium deposits. The results of the geochemical analyses show that the migmatite was greatly rich in $\mathrm{U}$ (up to $21.7 \mathrm{ppm}$ ) [14] and was 7 times more enriched in $U$ than the average continental crust $\left(2.8 \times 10^{-6} \mathrm{U}\right)[69]$. Thus, this migmatite was a dependable source of material for the uraninite in the Datian deposit.

\section{Conclusions}

1. The Datian uranium deposit is a high temperature hydrothermal uranium deposit. $\Sigma R E E$ is positively correlated with $Y$, and is poorly correlated with $U$ and is negatively correlated with Th in the Ur1 uraninite. These relationships demonstrate that the REEs, $Y$, and Th were originally incorporated into the Ur1 uraninite at the same time.

2. There are two phases of uraninite in the Datian migmatite hosted uranium deposit in the Kangdian region. They were formed by high temperature hydrothermal fluids, but their formation temperatures were significantly different. The phase 1 (Ur1) uraninite is characterized by the local development of microfractures and pores, distinct variations in crystal size, and irregular crystal shapes; while the phase 2 (Ur2) uraninite has anhedral crystal shapes with well-developed microfractures and pores. The Ur1 uraninite was formed during the first mineralization stage and is associated with ilmenite, biotite, and REE minerals (monazite and xenotime), whereas the Ur2 uraninite was formed from a secondary $S^{2-}$-rich hydrothermal fluid, along with pyrite, pyrrhotite, molybdenite, coffinite, zircon, and chlorite, and was accompanied by albitization and chloritization. The $\mathrm{ThO}_{2}$ and $\sum$ REE contents of the Ur2 uraninite are significantly higher than those of the Ur1 uraninite, and Ur2 uraninite is associated with high temperature minerals (molybdenite and pyrrhotite) and high temperature alteration (albitization). These facts indicate that the formation temperature of the Ur2 uraninite was higher than that of the Ur1 uraninite.

3. In-situ LA-ICP-MS U-Pb dating of the uraninite from the Datian uranium deposit provided two different ages of $834.5 \pm 4.1 \mathrm{Ma}$ and $837.2 \pm 4.5 \mathrm{Ma}$ and $841.4 \pm 4.0 \mathrm{Ma}$. These two ages are in excellent agreement with the ages of the migmatite in the Datian uranium deposit. Therefore, the Datian uranium deposit experienced at least two hydrothermal events, which led to the formation of the uraninite, and the uraninite are genetically related to the migmatite. The migmatite in the Zanli Formation provided the ore-forming material for the uranium mineralization.

4. The Datian uranium deposit represents a new type of migmatite hosted uranium deposit in the Kangdian region. Further studies of the U enrichment mechanisms of other migmatite hosted uranium deposits in the Kangdian region need to be conducted to evaluate their economic potentials. 
Supplementary Materials: The following are available online at https:/ / www.mdpi.com/article/10 $.3390 / \mathrm{min} 11101098 / \mathrm{s} 1$, Table S1: LA-ICP-MS U-Pb ages and trace and rare earth element data for the uraninite from the Datian uranium deposit.

Author Contributions: Conceptualization, L.C., C.Z. and H.S.; data curation, L.C., H.S. and Q.C.; formal analysis, L.C.; software, L.C.; investigation, L.C., C.Z., H.S. and Q.C.; resources, H.S. and Q.C.; methodology, L.C.; writing-original draft, L.C.; writing-review and editing, L.C.; funding acquisition, H.S. and Q.C.; supervision, C.Z. All authors have read and agreed to the published version of the manuscript.

Funding: This study was funded by the Sichuan Mineral Resources Research Center, grant number SCKCZY2021-YB009, the National Key R\&D Program of China, grant number 2018YFC0604202, the National Natural Science Foundation Program of China, grant number U1967207, and the Everest Scientific Research Program (CDUT).

Data Availability Statement: The data presented in this study are available in the Supplementary Materials in Table S1.

Acknowledgments: The authors thank Jian Yao for his help in collecting samples.

Conflicts of Interest: The authors declare no conflict of interest.

\section{References}

1. Ballouard, C.; Poujol, M.; Boulvais, P.; Mercadier, J.; Cuney, M. Magmatic and hydrothermal behavior of uranium in syntectonic leucogranites: The uranium mineralization associated with the Hercynian Guérande granite (Armorican Massif, France). Ore Geol. Rev. 2017, 80, 309-331. [CrossRef]

2. Zhong, J.; Wang, S.Y.; Gu, D.Z.; Cai, Y.Q.; Fan, H.H.; Shi, C.H.; Hu, C.N. Geology and fluid geochemistry of the Na-metasomatism $\mathrm{U}$ deposits in the Longshoushan uranium metallogenic belt, NW China: Constraints on the ore-forming process. Ore Geol. Rev. 2020, 116, 103214. [CrossRef]

3. Martz, P.; Mercadier, J.; Perret, J.; Villeneuve, J.; Deloule, E.; Cathelineau, M.; Quirt, D.; Doney, A.; Ledru, P. Post-crystallization alteration of natural uraninites: Implications for dating, tracing, and nuclear forensics. Geochim. Cosmochim. Acta 2019, 249, 138-159. [CrossRef]

4. Zhang, L.; Chen, Z.Y.; Wang, F.Y.; White, N.C.; Zhou, T.F. Release of Uranium from Uraninite in Granites Through Alteration: Implications for the Source of Granite-Related Uranium Ores. Econ. Geol. 2021, 116, 1115-1139. [CrossRef]

5. Jaireth, S.; Roach, I.C.; Bastrakov, E.; Liu, S. Basin-related uranium mineral systems in Australia: A review of critical features. Ore Geol. Rev. 2016, 76, 360-394. [CrossRef]

6. Cuney, M.; Emetz, A.; Mercadier, J.; Mykchaylov, V.; Shunko, V.; Yuslenko, A. Uranium deposits associated with Na-metasomatism from central Ukraine: A review of some of the major deposits and genetic constraints. Ore Geol. Rev. 2012, 44, 82-106. [CrossRef]

7. Eglinger, A.; André-Mayer, A.S.; Vanderhaeghe, O.; Mercadier, J.; Cuney, M.; Decrée, S.; Feybesse, J.L.; Milesi, J.P. Geochemical signatures of uranium oxides in the Lufilian belt: From unconformity-related to syn-metamorphic uranium deposits during the Pan-African orogenic cycle. Ore Geol. Rev. 2013, 54, 197-213. [CrossRef]

8. Eglinger, E.; Ferraina, C.; Tarantola, A.; André-Mayer, A.S.; Vanderhaeghe, O.; Boiron, M.C.; Dubessy, J.; Richard, A.; Brouand, M. Hypersaline fluids generated by highgrade metamorphism of evaporites: Fluid inclusion study of uranium occurrences in the Western Zambian Copperbelt. Contrib. Mineral. Petrol. 2014, 167, 967. [CrossRef]

9. Eglinger, A.; Tarantola, A.; Durand, C.; Ferraina, C.; Vanderhaeghe, O.; André-Mayer, A.S.; Paquette, J.L.; Deloule, E. Uranium mobilization by fluids associated with Ca-Na metasomatism: A P-T-t record of fluid-rock interactions during Pan-African metamorphism (Western Zambian Copperbelt). Chem. Geol. 2014, 386, 218-237. [CrossRef]

10. Eglinger, A.; Vanderhaeghe, O.; André-Mayer, A.S.; Goncalves, P.; Zeh, A.; Durand, C.; Deloule, E. Tectono-metamorphic evolution of the internal zone of the Pan-African Lufilian orogenic belt (Zambia): Implications for crustal reworking and syn-orogenic uranium mineralizations. Lithos 2016, 240-243, 167-188. [CrossRef]

11. Cosi, M.; De Bonis, A.; Gosso, G.; Hunziker, J.; Martinotti, G.; Moratto, S.; Robert, J.P.; Ruhlman, F. Late proterozoic thrust tectonics, high-pressure metamorphism and uranium mineralization in the Domes Area, Lufilian Arc, Northwestern Zambia. Precambrian Res. 1992, 58, 215-240. [CrossRef]

12. Zhang, C.J.; Chen, Y.L.; Li, J.C.; Xu, Z.Q.; Yao, J. The discovery of coarse-grained uraninite in Kangdian Axis and its geological significance. Geol. Bull. China 2015, 34, 2219-2226. (In Chinese with English Abstract)

13. Sun, Y.; Yao, J.; Li, J.C.; Sun, Z.X. Mineralization Characteristics and Origin of Extra Rich Uranium Deposits in Miyi-Yuanmou Area, Middle-South Part of Kangdian Axis. Uranium Geol. 2021, 37, 466-475. (In Chinese with English Abstract)

14. Yao, J. The Origin of the Migmatite Complex in the DaTian Area, Panzhihua City. Master's Thesis, Chengdu Univerisity of Technology, Chengdu, China, 2014.

15. Li, W.X. Migmatization and Uranium Mineralization in Haita Area of Miyi in Sichuan Province. Uranium Geol. $2018,34,346-352$. (In Chinese with English Abstract) 
16. Wang, F.L.; Yao, J. A new consideration on the genesis of uranium mineralization in Mouding, Yunnan: A new mineralization type related to albitite. Geol. Rev. 2020, 66, 739-754. (In Chinese with English Abstract)

17. Zheng, Y.W.; Chen, Y.L.; Peng, B.Y.; Hu, Y.; Guo, R.; Deng, Z. Geochemical Characteristics and Tectonic Significance of the Neoproterozoic Amphibolites from Datian area, Panzhihua City. Earth Sci. 2021, 46, 59-72. (In Chinese with English Abstract)

18. Sun, Z.X.; Chen, Y.L.; Yao, J.; Han, W.W.; Wang, F.L.; Zhang, L. Basic characteristics and genesis of the Datian uranium deposit in Panzhihua area, Western Sichuan. Geol. Rev. 2020, 66, 1005-1018. (In Chinese with English Abstract)

19. Yao, J.; Li, J.C.; Zhou, J.; Chen, G.P.; Yao, H.P. LA-ICP-MS zircon U-Pb dating of migmatite in Datian, Panzhihua City, and its geological significance. Geol. Bull. China 2017, 36, 381-391. (In Chinese with English Abstract)

20. Xu, Z.Q.; Zhang, C.J.; Ouyang, X.D.; Yao, J.; Sun, K.; Yin, M.H. Chronology Characteristics and Significance of Datian Uranium Deposit in Panzhihua. Uranium Geol. 2018, 33, 280-287. (In Chinese with English Abstract)

21. Bai, Y.; Xu, Z.Q.; Qin, Q.R.; Zhang, C.J.; Chen, Y.L. Geochronology and Its Geological Significance of Diabase/Granitic Dikes in Datian Area, Panzhihua. Uranium Geol. 2019, 35, 80-87. (In Chinese with English Abstract)

22. Yin, M.H.; Xu, Z.Q.; Song, H.; Zhang, S.H.; Zhang, C.J.; Li, T. Significant Geological Events Related to Uranium Mineralization in the Datian Area, Xikang-Yunnan Geo-Axis. Geol. Explor. 2021, 25, 124-135. (In Chinese with English Abstract)

23. Xu, Z.Q.; Ou, Y.X.D.; Zhang, C.J.; Yao, J.; Tang, M. Application of Electron Microprobe Chemical Dating to Datian Uraninite in Panzhihua and Its Significance. Rock Miner. Anal. 2017, 36, 641-648. (In Chinese with English Abstract)

24. Zhao, G.C. Jiangnan Orogen in South China: Developing from divergent double subduction. Gondwana Res. 2015, 27, 1173-1180. [CrossRef]

25. Zhao, G.C.; Cawood, P.A. Precambrian geology of China. Precambrian Res. 2012, 222-223, 13-54. [CrossRef]

26. Wang, Q.F.; Deng, J.; Li, C.S.; Li, G.J.; Yu, L.; Qiao, L. The boundary between the Simao and Yangtze blocks and their locations in Gondwana and Rodinia: Constraints from detrital and inherited zircons. Gondwana Res. 2014, 26, 438-448. [CrossRef]

27. Zhao, X.F.; Zhou, M.F.; Li, J.W.; Sun, M.; Gao, J.F.; Sun, W.H.; Yang, J.H. Late Paleoproterozoic to early Mesoproterozoic Dongchuan Group in Yunnan, SW China: Implications for tectonic evolution of the Yangtze Block. Precambrian Res. 2010, 182, 57-69. [CrossRef]

28. Shao, T.B.; Cheng, N.F.; Song, M.S. Provenance and tectonic-paleogeographic evolution: Constraints from detrital zircon U-Pb ages of Late Triassic-Early Jurassic deposits in the northern Sichuan basin, central China. J. Asian Earth Sci. 2016, $127,12-31$. [CrossRef]

29. Chen, W.T.; Sun, W.H.; Zhou, M.F.; Wang, W. Ca. 1050 Ma intra-continental rift-related A-type felsic rocks in the southwestern Yangtze Block, South China. Precambrian Res. 2018, 309, 22-44. [CrossRef]

30. Shellnutt, J.G. The Emeishan large igneous province: A synthesis. Geosci. Front. 2014, 5, 369-394. [CrossRef]

31. Zhao, B.Y.; Li, X.B.; Ying, J.L.; Li, J.Y.; Xu, Z.Y.; Hou, Y.X. Certified Reference Material for U-Pb Isotopic Dating; Beijing Research Institute of Uranium Geology: Beijing, China, 1996. (In Chinese)

32. Zong, K.Q.; Cheng, J.Y.; Hu, Z.C.; Liu, Y.S.; Li, M.; Fan, H.H.; Meng, Y.N. In-Situ U-Pb dating of uraninite by fs-LA-ICP-MS. Earth Sci. 2015, 58, 1731-1740. [CrossRef]

33. Feng, M.Y.; Rong, J.S.; Sun, Z.F.; Xu, Z.Y.; Xie, H.J. Pegmatitic Uranium Deposit in the North Qinling; Atomic Energy Press: Beijing, China, 1996. (In Chinese)

34. Guo, G.L.; Zhang, Z.S.; Liu, X.D.; Feng, Z.S.; Lai, D.R.; Zhou, W.R. EPMA chemical U-Th-Pb dating of uraninite in guangshigou uranium deposit. J. East China Inst. Technol. 2012, 35, 309-314. (In Chinese with English Abstract)

35. Wu, Y.; Qin, M.K.; Guo, D.F.; Fan, G.; Liu, Z.Y.; Guo, G.L. The Latest In-Situ uraninite U-Pb age of the Guangshigou uranium deposit, Northern Qinling Orogen, China: Constraint on the Metallogenic Mechanism. Acta Geol. Sin. 2018, 92, 389-391. [CrossRef]

36. Yuan, F.; Liu, J.J.; Carranza, E.J.M.; Zhai, D.G.; Wang, Y.H.; Zhang, S.; Sha, Y.Z.; Liu, G.; Wu, J. The Guangshigou uranium deposit, northern Qinling Orogen, China: A product of assimilation-fractional crystallization of pegmatitic magma. Ore Geol. Rev. 2018, 99, 17-41. [CrossRef]

37. Liu, Y.S.; Hu, Z.C.; Gao, S.; Günther, D.F.; Xu, J.; Gao, C.; Chen, H.H. In Situ Analysis of Major and Trace Elements of Anhydrous Minerals by LA-ICP-MS without Applying an internal Standard. Chem. Geol. 2008, 257, 34-43. [CrossRef]

38. Duffin, A.M.; Springer, K.W.; Ward, J.D.; Jarman, K.D.; Robinson, J.W.; Endres, M.C.; Hart, G.L. Femtosecond laser ablation multicollector ICPMS analysis of uranium isotopes in NIST glass. J. Anal. At. Spectrom. 2015, 30, 1100-1107. [CrossRef]

39. Liu, Y.S.; Hu, Z.C.; Zong, K.Q. Reappraisement and refinement of zircon U-Pb isotope and trace element analyses by LA-ICP-MS Chin. Sci. Bull. 2010, 55, 1535-1546. (In Chinese with English Abstract) [CrossRef]

40. Chen, L.L.; Chen, Y.; Feng, X.; Li, J.G.; Guo, H.; Miao, P.; Jin, R.; Tang, C.; Zhao, H.; Wang, G.; et al. Uranium occurrence state in the Tarangaole area of the Ordos Basin, China: Implications for enrichment and mineralization. Ore Geol. Rev. 2019, 115, 103034. [CrossRef]

41. Ozha, M.K.; Pal, D.C.; Mishra, B.; Desapati, T.; Shaji, T.S. Geochemistry and chemical dating of uraninite in the Samarkiya area, central Rajasthan, northwestern India-Implication for geochemical and temporal evolution of uranium mineralization. Ore Geol. Rev. 2017, 88, 23-42. [CrossRef]

42. Mercadier, J.; Cuney, M.; Lach, P.; Boiron, M.C.; Bonhoure, J.; Richard, A.; Leisen, M.; Kister, P. Origin of uranium deposits revealed by their rare earth element signature. Terra Nova 2011, 23, 264-269. [CrossRef] 
43. Frimmel, H.E.; Schedel, S.; Brätz, H. Uraninite chemistry as forensic tool for provenance analysis. Appl. Geochem. 2014, 48, 104-121. [CrossRef]

44. Anders, E.; Grevesse, N. Abundances of the elements: Meteoritic and solar. Geochim. Cosmochim. Acta 1989, 53, 197-214. [CrossRef]

45. Finch, R.J.; Ewing, R.C. The corrosion of uraninite under oxidizing conditions. J. Nucl. Mater. 1992, 190, 133-156. [CrossRef]

46. Janeczek, J.; Ewing, R.C. Structural formula of uraninite. J. Nucl. Mater. 1992, 190, 128-132. [CrossRef]

47. Evron, R.; Kimmel, G.; Eyal, Y. Thermal recovery and self-radiation damage in uraninite and thorianite. J. Nucl. Mater. 1994, 217, 54-66. [CrossRef]

48. Fayek, M.; Kyser, T.K. Low temperature oxygen isoope fractionation in the uraninite- $\mathrm{UO}_{3}-\mathrm{CO}_{2}-\mathrm{H}_{2} \mathrm{O}$ system. Geochim. Cosmochim. Acta 2000, 64, 2185-2197. [CrossRef]

49. Deditius, A.P.; Utsunomiya, S.; Ewing, R.C. Alteration of $\mathrm{UO}_{2+\mathrm{x}}$ under oxidizing conditions, Marshall Pass, Colorado, USA. J. Alloy. Compd. 2007, 444-445, 584-589. [CrossRef]

50. Depiné, M.; Frimmel, H.E.; Emsbo, P.; Koenig, A.E.; Kern, M. Trace element distribution in uraninite from Mesoarchaean Witwatersrand conglomerates (South Africa) supports placer model and magmatogenic source. Miner. Depos. 2013, 48, 423-435. [CrossRef]

51. Pal, D.C.; Rhede, D. Geochemistry and chemical dating of uraninite in the Jaduguda uranium deposit, Singhbhum Shear Zone, India-implications for uranium mineralization and geochemical evolution of uraninite. Econ. Geol. 2013, 108, 1499-1515. [CrossRef]

52. Macmillan, E.; Cook, N.J.; Ehrig, K.; Ciobanu, C.L.; Pring, A. Uraninite from the Olympic Dam IOCG-U-Ag deposit: Linking textural and compositional variation to temporal evolution. Am. Mineral. 2016, 101, 1295-1320. [CrossRef]

53. Mukhopadhyay, J.; Mishra, B.; Chakrabarti, K.; De, S.; Ghosh, G. Uraniferous paleoplacers of the Mesoarchean Mahagiri Quartzite, Singhbhum craton, India: Depositional controls, nature and source of $>3.0$ Ga detrital uraninites. Ore Geol. Rev. 2016, 72, 1290-1306. [CrossRef]

54. Shannon, R.D. Revised effective ionic radii and systematic studies of interatomic distances in halides and chalcogenides. Acta Crystallogr. Section A 1976, 32, 751-767. [CrossRef]

55. Alexandre, P.; Kyser, K.; Layton-Matthews, D.; Joy, B. Chemical Compositions of Natural Uraninite. Can. Mineral. 2015, 53, 595-662. [CrossRef]

56. Förster, H.J. The chemical composition of uraninite in Variscan granites of the Erzgebirge, Germany. Mineral. Mag. 1999, 63, 239-252. [CrossRef]

57. Cuney, M. Evolution of uranium fractionation processes through time: Driving the secular variation of uranium deposit types. Econ. Geol. 2010, 105, 553-569. [CrossRef]

58. Grandstaff, D.E. A kinetic study of the dissolution of uraninite. Econ. Geol. 1976, 71, 1493-1506. [CrossRef]

59. Alexandre, P.; Kyser, K.; Polito, P.; Thomas, D. Alteration mineralogy and stable isotope geochemistry of Paleoproterozoic basement-hosted unconformity-type uranium deposits in the Athabasca Basin, Canada. Econ. Geol. 2005, 100, 1547-1563. [CrossRef]

60. Mercadier, J.; Annesley, I.R.; McKechnie, C.L.; Bogdan, T.S.; Creighton, S. Magmatic and Metamorphic Uraninite Mineralization in the Western Margin of the Trans-Hudson Orogen (Saskatchewan, Canada): A Uranium Source for Unconformity-Related Uranium Deposits? Econ. Geol. 2013, 108, 1037-1065. [CrossRef]

61. Fayek, M.; Horita, J.; Ripley, E.M. The oxygen isotopic composition of uranium minerals: A review. Ore Geol. Rev. 2011, 41, 1-21. [CrossRef]

62. Keegan, E.; Wallenius, M.; Mayer, K.; Varga, Z.; Rasmussen, G. Attribution of uranium ore concentrates using elemental and anionic data. Appl. Geochem. 2012, 27, 1600-1609. [CrossRef]

63. Lach, P.; Mercadier, J.; Dubessy, J.; Boiron, M.C.; Cuney, M. In Situ quantitative measurement of rare earth elements in uranium oxides by laser ablation-inductively coupled plasmamass spectrometry. Geostand. Geoanalytical Res. 2013, 37, 277-296. [CrossRef]

64. Uvarova, Y.A.; Kyser, T.K.; Geagea, M.L.; Chipley, D. Variations in the uranium isotopic compositions of uranium ores from different types of uranium deposits. Geochim.Cosmochim. Acta 2014, 146, 1-17. [CrossRef]

65. Spano, T.L.; Simonetti, A.; Balboni, E.; Dorais, C.; Burns, P.C. Trace element and U isotope analysis of uraninite and ore concentrate: Applications for nuclear forensic investigations. Appl. Geochem. 2017, 84, 277-285. [CrossRef]

66. Ghiorso, M.S.; Evans, B.W. Thermodynamics of Rhombohedral Oxide Solid Solutions and a Revision of the FE-TI Two-Oxide Geothermometer and Oxygen-Barometer. Am. J. Sci. 2008, 308, 957-1039. [CrossRef]

67. Zhu, Z.M.; Tan, H.Q.; Liu, Y.D.; Li, C. Multiple episodes of mineralization revealed by Re-Os molybdenite geochronology in the Lala Fe-Cu deposit, SW China. Miner. Depos. 2018, 53, 311-322. [CrossRef]

68. Song, H.; Chi, G.X.; Zhang, C.J.; Xu, D.R.; Xu, Z.Q.; Fan, G.; Zhang, G.Y. Uranium enrichment in the Lala Cu-Fe deposit, Kangdian region, China: A new case of uranium mineralization associated with an IOCG system. Ore Geol. Rev. 2020, $121,103463$. [CrossRef]

69. Taylor, S.R.; McLennan, S.M. The geochemical evolution of the continental crust. Rev. Geophys. 1995, 33, 242-265. [CrossRef] 